\title{
Tectonic evolution of the west Scotia Sea
}

\author{
Graeme Eagles, ${ }^{1}$ Roy A. Livermore, ${ }^{2}$ J. Derek Fairhead, ${ }^{3}$ and Peter Morris ${ }^{2}$ \\ Received 26 April 2004; revised 28 October 2004; accepted 12 November 2004; published 2 February 2005.
}

[1] Joint inversion of isochron and flow line data from the flanks of the extinct West Scotia Ridge spreading center yields five reconstruction rotations for times between the inception of spreading prior to chron $\mathrm{C} 8(26.5 \mathrm{Ma})$, and extinction around chron $\mathrm{C} 3 \mathrm{~A}$ $(6.6-5.9 \mathrm{Ma})$. When they are placed in a regional plate circuit, the rotations predict plate motions consistent with known tectonic events at the margins of the Scotia Sea: Oligocene extension in Powell Basin; Miocene convergence in Tierra del Fuego and at the North Scotia Ridge; and Miocene transpression at the Shackleton Fracture Zone. The inversion results are consistent with a spreading history involving only two plates, at rates similar to those between the enclosing South America and Antarctica plates after chron C5C

$(16.7 \mathrm{Ma})$, but that were faster beforehand. The spreading rate drop accompanies inception of the East Scotia Ridge back-arc spreading center, which may therefore have assumed the role of the West Scotia Ridge in accommodating eastward motion of the trench at the eastern boundary of the Scotia Sea. This interpretation is most easily incorporated into a model in which the basins in the central parts of the Scotia Sea had already formed by chron $\mathrm{C} 8$, contrary to some widely accepted interpretations, and which has significant implications for paleoceanography and paleobiogeography.

Citation: Eagles, G., R. A. Livermore, J. D. Fairhead, and P. Morris (2005), Tectonic evolution of the west Scotia Sea, J. Geophys. Res., 110, B02401, doi:10.1029/2004JB003154.

\section{Introduction}

[2] Situated in the southwestern Atlantic, the Scotia Sea (Figure 1) is currently an important biogeographic [Tunnicliffe et al., 1998; German et al., 2000] and oceanographic [Heywood et al., 2002] interchange, and has long been recognized to have been similarly important in the geological past [Kennett et al., 1975; Barker and Burrell, 1977; Woodburne and Zinsmeister, 1982; Case et al., 1988; Beu et al., 1997; Livermore et al., 2004]. Although it bears directly on the region's role in oceanographic and biogeographical change, the tectonic evolution of the Scotia Sea is the subject of relatively few original studies, most dating from the mid 1980s or before. This paper focuses on the tectonic history of the extinct West Scotia Ridge seafloor spreading system in the western part of the Scotia Sea.

[3] Barker and Burrell [1977] were the last to study the history of seafloor spreading at the West Scotia Ridge in detail; they produced a reconstruction of magnetic anomaly C8 ( 26.5 Ma; we use the magnetic anomaly timescale of Cande and Kent, [1995] throughout) by manual manipulation of a printed polar stereographic projection. Using the

\footnotetext{
${ }^{1}$ Alfred Wegener Institute for Polar and Marine Research, Bremerhaven, Germany.

${ }^{2}$ British Antarctic Survey, Cambridge, UK

${ }^{3}$ GeTECH, University of Leeds, Leeds, UK.
}

same data set, Burrell [1983] performed least squares fits of picks of anomalies C5 ( 10 Ma), C6 ( 20 Ma) and C8, but these were never published. Later work, and many reviews, have addressed the rest of the Scotia Sea, and it is in this context that the west Scotia Sea is now best known, often interpreted as one of a complex of back-arc basins that evolved in response to ridge-crest-trench collisions in the northern Weddell Sea [Barker, 1995, 2001; King and Barker, 1988; Barker et al., 1982, 1984, 1991; Lawver and Gahagan, 2003]. Here we present a new set of reconstruction rotations for the West Scotia Ridge, based on joint inversion of newly compiled magnetic anomaly data and flow line structures derived from gridded satellite gravity anomalies. We use these results to examine the wider tectonic role of the West Scotia Ridge as a complication of the evolving South America-Antarctica plate boundary.

\section{Scotia Sea Structure}

[4] The floor of the Scotia Sea (Figure 1) consists of subsided continental blocks at Pirie Bank and Bruce Bank [Garrett et al., 1986; Mao and Mohr, 1995], three relatively large oceanic basins, and four smaller and less well-known basins. The largest basin, the west Scotia Sea, was created during Oligocene and Miocene times at the now-extinct West Scotia Ridge spreading center. To the southwest, the west Scotia Sea borders a fragment of the former Phoenix plate [Barker, 1982] at the Shackleton Fracture Zone [Livermore et al., 2004]. A province of east striking seafloor spreading anomalies in the central Scotia Sea lies 


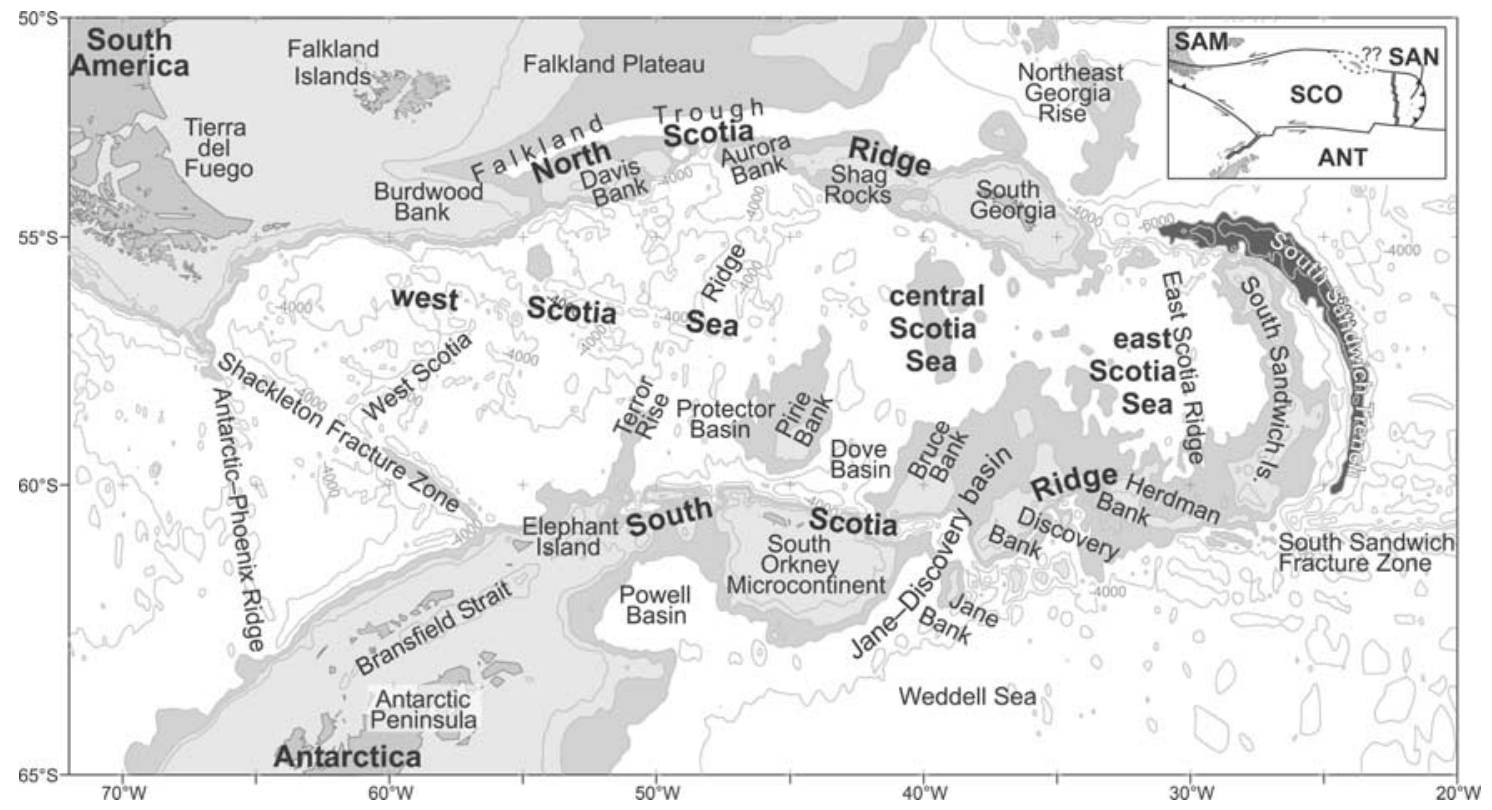

Figure 1. Bathymetric contour map of the Scotia Sea (based on British Antarctic Survey archived data). Light gray shading indicates depths shallower than $2000 \mathrm{~m}$; midgray, shallower than $3000 \mathrm{~m}$; dark gray, deeper than $6000 \mathrm{~m}$. Inset shows present-day plate tectonic setting, after Thomas et al. [2003]. Abbreviations are as follows: SAM, South America plate; ANT, Antarctic plate; SAN, Sandwich plate; SCO, Scotia plate. Double lines indicate spreading centers; single lines with half arrows indicate strikeslip boundaries; barbed lines indicate subduction zones (barbs on overriding plate).

to the northeast [Barker, 1970] and, to the southeast, there is a region of slightly shallower seafloor of unknown origin that we term Terror Rise, after the ship of James Clark Ross. These features are presumed to be the conjugates to the continental rise of Tierra del Fuego and western parts of the North Scotia Ridge. There has been, and continues to be, speculation about the tectonic evolution of the central Scotia Sea and its relationship to the west Scotia Sea. The two basins may have formed contemporaneously [Hill and Barker, 1980] or the central Scotia Sea may be a much older feature [De Wit, 1977]. The east Scotia Sea is an active back-arc basin behind the South Sandwich subduction zone that opens by seafloor spreading at the East Scotia Ridge [Barker, 1972, 1995; Vanneste and Larter, 2002].

[5] A chain of islands and submarine highs, termed the Scotia Arc (Figure 1), encircles the Scotia Sea. Its northern arm, the North Scotia Ridge, forms an offshore continuation of the Magallanes fault zone of Tierra del Fuego and, with it, the northern boundary of the Scotia Sea. The North Scotia Ridge reaches from Tierra del Fuego to South Georgia and contains rocks like those of Mesozoic South America [Macfadyen, 1933; Tyrrell, 1945; Dalziel et al., 1975; Storey and Macdonald, 1984]. The Falkland Trough, a Cenozoic foreland basin [Bry et al., 2004], separates the North Scotia Ridge from the Falkland Plateau on the South America plate. The eastern and southern reaches of the Scotia Arc (respectively the South Sandwich Islands and the southeastern edge of the South Scotia Ridge) are constituted of active and inactive parts of volcanic arcs that formed above the South Sandwich subduction zone and its predecessors [Barker et al., 1982, 1984; Livermore et al., 1994; Barker, 1995]. Collisions of segments of the South American-Antarctic Ridge with the subduction zone, and subduction-erosion further north, caused piecemeal deactivation and destruction of the arc starting somewhere south of the South Orkney Microcontinent and stepping northeastward to Jane Bank by magnetic chron C6A $(\sim 21 \mathrm{Ma})$, and Discovery Bank by chrons C5-C3 (11.5-4 Ma) [Barker et al., 1982, 1984; Hamilton, 1989; Vanneste and Larter, 2002]. The East Scotia Ridge, North Scotia Ridge, Shackleton Fracture Zone, South Scotia Ridge and South Sandwich Trench define the present-day Sandwich and Scotia plates within the Scotia Sea (Figure 1, inset [Thomas et al. [2003]).

\section{Inversion for West Scotia Sea Plate Motion}

[6] Burrell's [1983] least squares inversion used the interpretations, data, and starting assumptions of Barker and Burrell [1977] and produced similar reconstructions. The inversion results are rather poorly constrained, being unable to differentiate between divergence and convergence after chron C5 in a three-plate setting at the 95\% confidence level. Satellite-derived free-air gravity anomalies [Sandwell and Smith, 1997] have since become available that show fracture zones (FZs) on the flanks of the West Scotia Ridge, and reveal that these studies inadvertently grouped some isochron pairs from different spreading corridors as conjugates, while the total length of magnetic anomaly profiles in the Scotia Sea is now $\sim 40 \%$ greater than that available to Barker and Burrell in 1977. We used the inversion technique of Nankivell [1997], a realization of Shaw and Cande's [1990] technique with extensions, to 


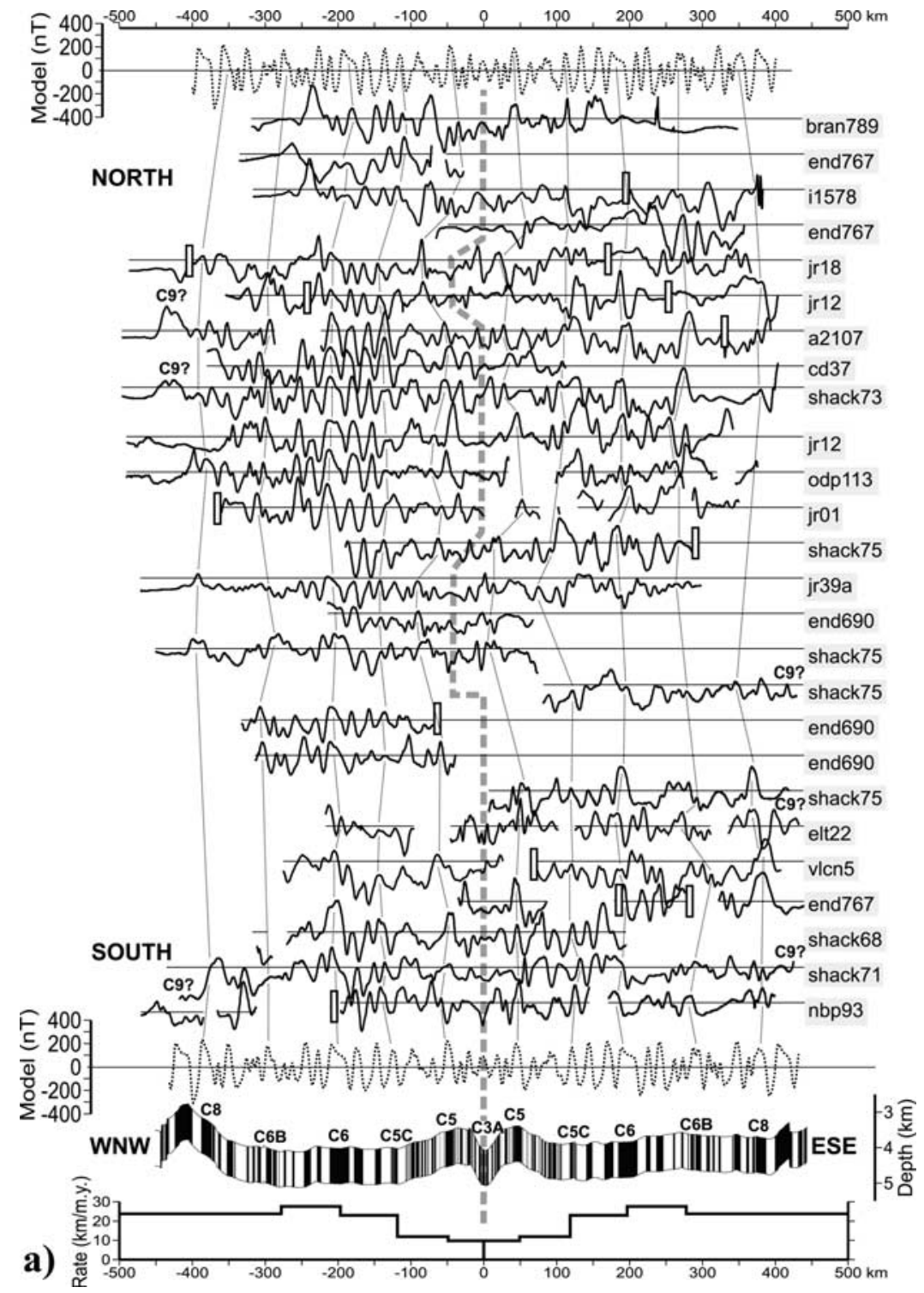

Figure 2. (a) Selected west Scotia Sea magnetic anomaly profiles projected onto $120^{\circ}$ (solid lines), compared to a model (dotted line) made with a $1 \mathrm{~km}$ thick source layer whose upper surface is the average of the bathymetry along the tracks shown, with effective susceptibility of 0.07 . Thin dotted lines are correlation lines for the peaks of anomalies C8, C6B, C6, C5C, and C5; dashed gray line marks the West Scotia Ridge axis as defined by free-air gravity anomalies. Short white bars are FZ crossings. (b) Bathymetric profiles along some of the same ship tracks as in Figure 2a compared to a theoretical subsidence curve (thick gray line) calculated for the flanks of the West Scotia Ridge, using the same spreading rates as in Figure $2 \mathrm{a}$ and a zero-age depth of $2.5 \mathrm{~km}$.

generate a set of reconstruction parameters for the west Scotia Sea. In this study, the extended features are not used and the inversion technique functions identically to that of Shaw and Cande [1990]. The expanded data set, different starting assumptions, and quantitative reconstruction technique mean that we can calculate a better constrained set of finite rotation parameters for the west Scotia Sea than the earlier studies. In the following, we refer to the northwest and southeast flanks of the West Scotia Ridge as its Magallanes and Central Scotia flanks, respectively, and to spreading corridors, formed at seven axial spreading center segments, as W1 to W7, from southwest to northeast.

\subsection{Magnetic Data and Magnetic Isochron Picks}

[7] Figure 2a shows representative models of magnetic reversal anomalies compared to observed anomaly profiles. There are identifiable anomaly sequences, or partial sequences, in all parts of the west Scotia Sea, similar to those published by Barker and Burrell [1977] and Livermore et al. [1994], and to some of the isochrons shown in the tectonic map of the British Antarctic Survey [1985], but here 

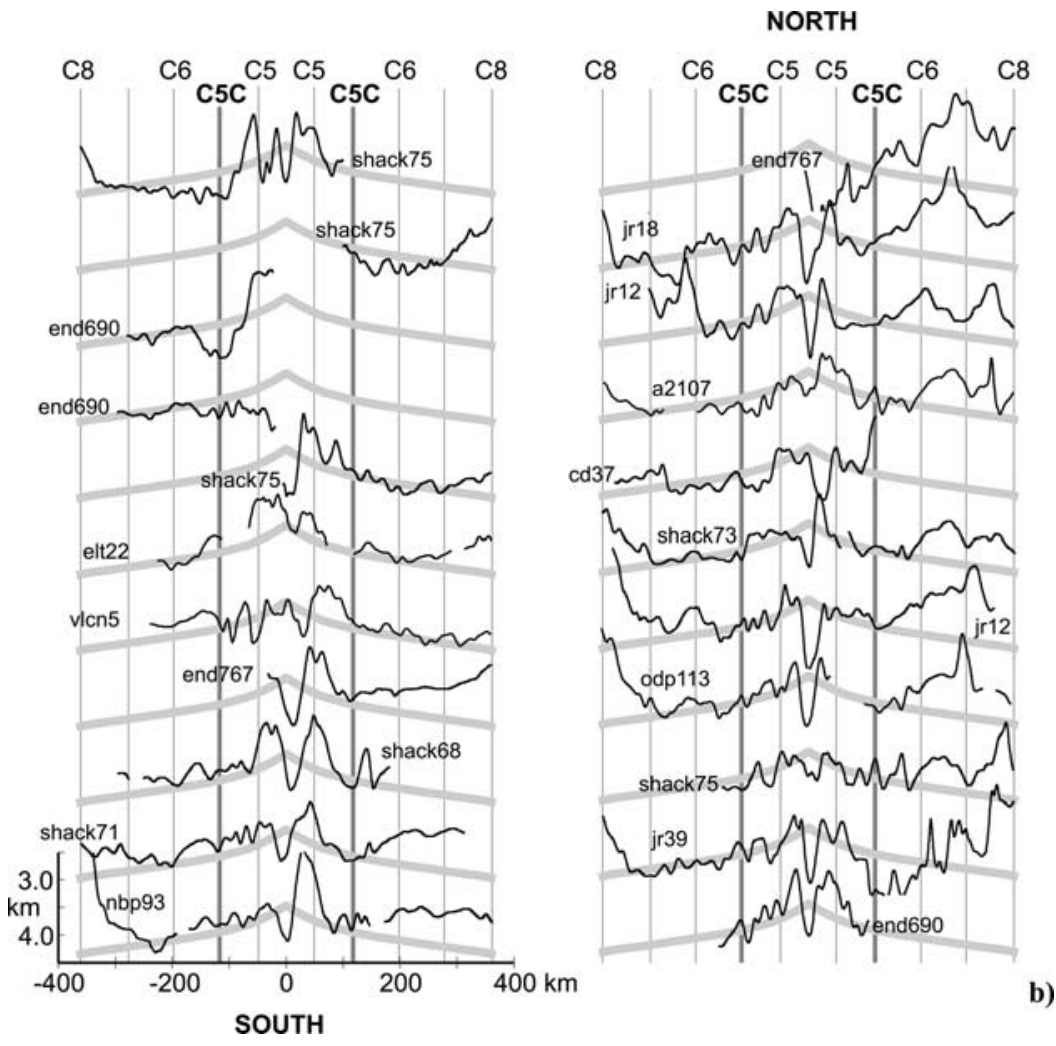

Figure 2. (continued)

the precise picks of anomaly edges, and their assignment to spreading corridors, are different.

[8] Uncertainty in the age of extinction on many profiles stems from the complexity and inconsistency of the axial anomalies, because of slow spreading, asymmetric accretion [Livermore et al., 1994], and possibly postextinction tectonism [e.g., Maldonado et al., 2000]. The time of extinction is within the normal polarity parts of chron $\mathrm{C} 3 \mathrm{~A}$ $(\sim 6.6-5.9 \mathrm{Ma})$ on the profiles where axial anomalies are well developed. Anomalies as old as C10 ( 28.7 Ma) have been identified off the Tierra del Fuego margin [Barker and Burrell, 1977; LaBrecque and Rabinowitz, 1977] and near Terror Rise [Lodolo et al., 1997]. Those anomalies older than $\mathrm{C} 8$ are incoherent between tracks and, apart from corridor W1, lack conjugates in their own spreading corridors. Although they can be interpreted as indicative of complicated processes during early seafloor spreading [Barker and Burrell, 1977], these older anomalies are too poorly understood to be of use here. The old edge of anomaly $\mathrm{C} 8$ is the oldest consistently identifiable magnetic anomaly in the west Scotia Sea. At the margin of Davis Bank, part of the North Scotia Ridge (Figures 1 and 3a) bordering corridors W6 and W7 on the Magallanes flank, the oldest identifiable anomalies become younger toward the north until, at $54^{\circ} \mathrm{S}$, the oldest anomaly is C6. The relationship of these anomalies to Davis Bank is unlikely to indicate simple northward ridge propagation in corridor W6, however, because their onlapping pattern is not mirrored on the Central Scotia flank, where older anomalies are present instead. Aurora Bank (Figures 1 and 3a) is part of the North Scotia Ridge that lies to the north of W7, beneath which it is possible to interpret continuations of $\mathrm{C} 5 \mathrm{C}(\sim 16.7 \mathrm{Ma})$ and the younger anomaly sequence from $\mathrm{W} 7$.

[9] We identify anomalies C5, C5C, C6, C6B ( 23.1 Ma) and $\mathrm{C} 8$ for our inverse model. The profiles are best modeled by spreading rates of $\sim 25 \mathrm{~km} / \mathrm{m}$.y. between chrons $\mathrm{C} 8$ and C5D/C5C ( 17.6-16.7 Ma), and $\sim 10 \mathrm{~km} / \mathrm{m} . \mathrm{y}$. afterward, and by introducing a slight spreading asymmetry that favors the Central Scotia flank by $4-6 \%$ before the spreading rate decrease. Identification of anomalies in segments W3 and W4 is hampered by a dearth of suitably oriented ship tracks and, on the Central Scotia flank, by incoherency at short wavelengths between profiles (Figures 2a). This incoherency is confined to lithosphere older than $\mathrm{C} 5 \mathrm{C}$ and increases toward the northeast and toward older anomalies. The region of incoherent anomalies also displays a significant deviation - by up to $1 \mathrm{~km}$ or more - from a theoretical thermal subsidence profile (Figure 2b). These observations may be taken as evidence for uplift, or retarded subsidence, of the lithosphere, by processes that were active on the Central Scotia flank until around $17 \mathrm{Ma}$.

[10] A grid of magnetic total field anomalies in the west Scotia Sea aids the interpretation of data from the numerous ship tracks that run oblique to flow lines (Figure 3a). Only satellite-navigated ship track data were used to create the grid, mostly acquired by ships of the British Antarctic Survey, its predecessors, and the Royal Navy, although many other vessels have surveyed the area. Most of the data were collected using towed proton precession magnetometers. Many magnetic records are long, with segments often representing several days' recording. Such tracks were split, usually at significant course changes or short pauses, 

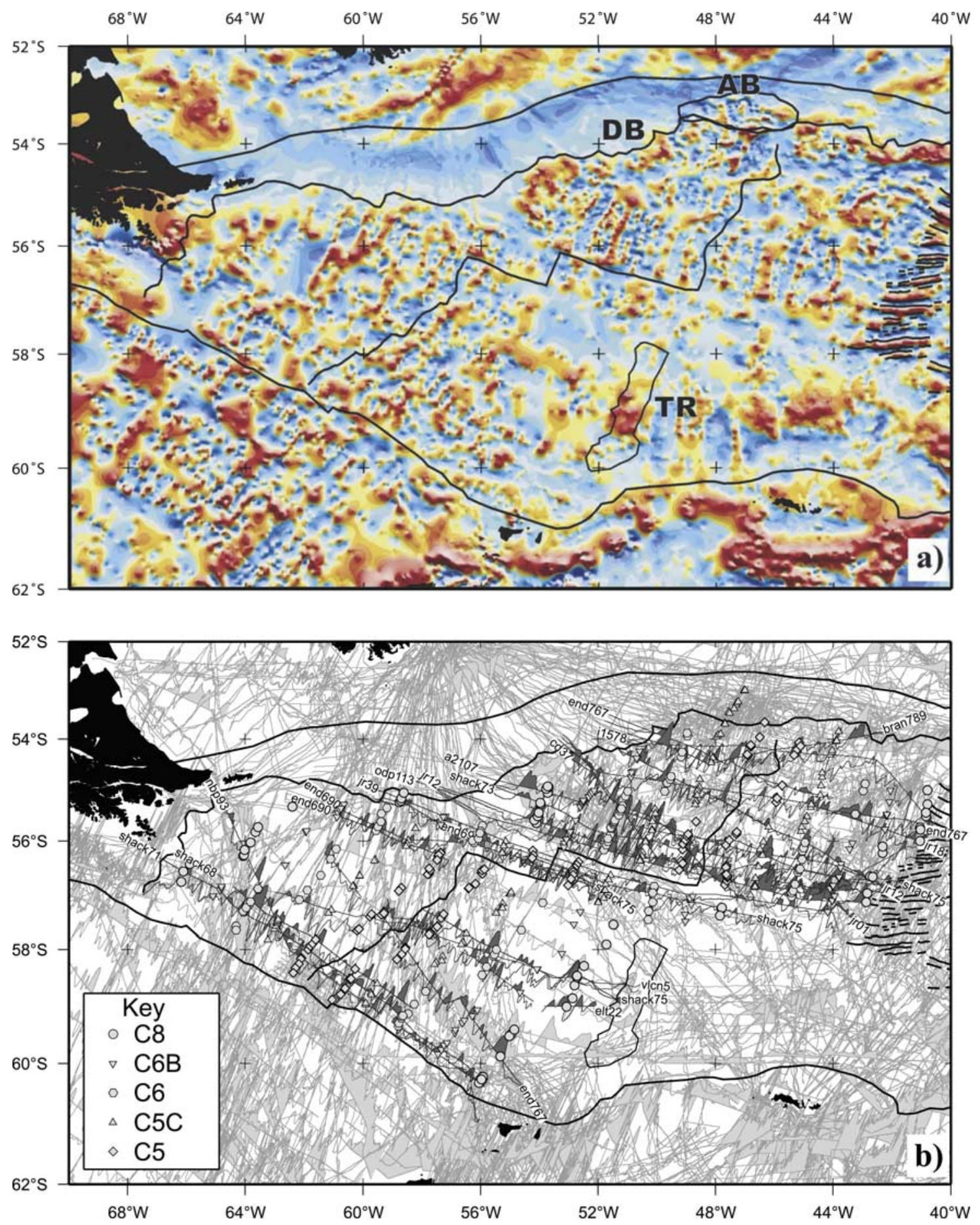

Figure 3. (a) Total field anomaly grid for the Scotia Sea. Abbreviations are as follows: AB, Aurora Bank; DB, Davis Bank; TR, Terror Rise. (b) Ship tracks and anomaly wiggles with magnetic anomaly picks used in the inversion. Named ship tracks are those displayed in Figures $2 \mathrm{a}-2 \mathrm{~b}$. Not all of the ship tracks shown supplied data to create the grid in Figure 3a. Black lines highlight the margins of the west Scotia Sea and the province of east striking magnetic anomalies in the central Scotia Sea.

in order to allow network adjustment programs to work efficiently. No diurnal corrections could be made in the absence of suitable base station records. Obvious spikes and noisy sections were removed by manual editing. The DGRF/IGRF field value appropriate to the time and location of acquisition was subtracted before leveling. Network adjustment, with the X-System [Wessel, 1989], reduced crossover errors from a mean and standard deviation of $15 \mathrm{nT} / 62 \mathrm{nT}$ to $0.1 \mathrm{nT} / 32 \mathrm{nT}$. The unweighted data were then gridded at an interval of 2 minutes using a continuous 
curvature spline-in-tension technique [Smith and Wessel, 1990].

[11] We overlaid all of the magnetic anomaly profiles available to us on the grid in order to identify anomaly crossings. The final set of 413 isochron picks (Figure $3 \mathrm{~b}$ ) is an order of magnitude larger than the data set used by Burrell [1983].

\subsection{Free-Air Anomaly Data and FZ Picks}

[12] Linear troughs in gridded satellite-derived free-air gravity anomalies identify the positions of FZs. Figure 4 shows three FZs that are continuous on both flanks: the Shackleton, Quest, and Endurance FZs. The free-air anomalies define seven spreading segments at the time of West Scotia Ridge extinction, and magnetic isochrons and FZ anomalies show that this segmentation appears to have come into existence close to the decrease in spreading rate at around chron $\mathrm{C} 5 \mathrm{C}$, accompanying an increase in the free-air gravity anomaly amplitude, bathymetric slope, and bathymetric roughness, on the flanks of the West Scotia Ridge [Livermore et al., 1994]. The anomalies associated with the median valley are rotated clockwise with respect to anomaly $\mathrm{C} 5$ and older magnetic isochrons, and the accompanying clockwise rotation of FZ anomalies also starts ridgeward of C5, suggesting that subsegmentation of the West Scotia Ridge and the spreading rate drop preceded the rotation of subsegments by several million years.

[13] The northernmost transform offset of the ridge is connected to a linear trough on the Magallanes flank that we refer to as the Burdwood FZ (Figure 4). The offsets of magnetic isochrons at the Burdwood FZ are much shorter than the offset of the extinct ridge crest at the transform fault until some time after chron $\mathrm{C} 5$. The extinct transform fault and parts of its continuation that are younger than chron $\mathrm{C} 5 \mathrm{C}$ on the Central Scotia flank are not copolar with any of the other FZs in the west Scotia Sea. A strong, wide, negative free-air anomaly is formed over the transform fault, and multibeam bathymetric data (British Antarctic Survey, unpublished data, 2004) show a deep, steep-sided basin, with a smooth floor, that may have formed during transtension - an occurrence that may explain the late stage increase in magnetic anomaly offset. This basin has been previously referred to as the Scotia Trough [Hill, 1978] or, rather misleadingly, as the Tehuelche FZ on GEBCO charts since 1981. To avoid confusion, we refer to this feature simply as "the deep trough east of the Burdwood FZ."

[14] In corridor W6, paleosegmentation is not easy to interpret on the basis of free-air anomalies alone. The pattern of coherent magnetic anomalies on the Magallanes flank requires there to have been two offsets within W6 at C8 time. Free-air gravity anomaly troughs or gradients parallel to flow lines coincide with these offsets, and merge into a single feature between anomalies C6 and C5C, consistent with the segmentation based on picks of the younger magnetic anomalies. This offset appears to have migrated northeast after $\mathrm{C} 5 \mathrm{C}$, and to have tracked the latestage rotation of the central subsegment of the ridge in W6 (Figure 4).

[15] The Shackleton FZ is the most prominent feature transverse to the West Scotia Ridge in free-air anomaly and bathymetric data, because of the presence of a steep-sided ridge southeast of the FZ's intersection with the ridge crest in W1 (Figures 4 and 5 [Livermore et al. [2004]). Although the Shackleton FZ has long been treated as an indicator of relative movements between South America and the Antarctic Peninsula [Barker and Burrell, 1977; Cunningham et al., 1995], this is a misconception. The Shackleton FZ's tectonic development was dominated by movements dictated by the rapid southeastward absolute motion of the Phoenix plate with respect to the much slower Antarctica and Scotia Sea plates, and also involved some late transpressional strain [Eagles, 2003; Livermore et al., 2004]. Figure 5 demonstrates that it is also inappropriate to treat the Shackleton FZ as a flow line of relative motion within the west Scotia Sea. While the West Scotia Ridge was active, two plates occupied the region northeast of the Shackleton Fracture Zone: one either side of the West Scotia Ridge in W1. These would have been a "Magallanes" plate and a "Central Scotia" plate for times when motion occurred on both the North Scotia Ridge and South Scotia Ridge. If there were no motion on the North Scotia Ridge, then the South America plate would have occupied the northwest flank of the West Scotia Ridge. If there were no motion on the South Scotia Ridge, the Antarctica plate would have occupied the southeast flank of the West Scotia Ridge. Hence, until West Scotia Ridge extinction, the length of the Shackleton FZ between points A and B (Figure 5) experienced relative motion in either the South America-Antarctica or Magallanes-Antarctica system, the length between B and C acted in either the South AmericaPhoenix or Magallanes-Phoenix system, shortening all the while, and the length between points $\mathrm{C}$ and $\mathrm{D}$ would have recorded either Antarctica-Phoenix or Central ScotiaPhoenix motion. No segment of the Shackleton FZ could ever have formed because of relative movements between the Magallanes and Central Scotia plates, meaning that no part of its trace is a simple record of such movements. For this reason, we do not include any data from the Shackleton FZ in our inversion.

[16] We also considered the possibility that movements across the long offsets of the Endurance and Quest FZs might have made them unsuitable for the inversion process [Cande et al., 1988; Müller and Roest, 1992]. The fossil transform fault on the Endurance FZ shows a subtle change in curvature at $\sim 52^{\circ} \mathrm{W}$ in free-air gravity maps and does not follow a single small circle (Figure 4). A free-air gravity ridge on the northern flank of the fossil transform east of this inflection suggests that the eastern part of the transform may have accommodated some across-axis strain. A similar feature exists on the Central Scotia flank south of the Quest FZ. Depending on the timing of this strain, the Quest and Endurance FZs thus have the potential to bias the results of any inversion using data from them.

[17] The remaining FZs were assessed for selection based on the following criteria: (1) visual assessment of membership of the largest set of copolar trough features in the west Scotia Sea, that appears to have formed about Euler poles to the NNE; (2) length in excess of $30 \mathrm{~km}$ (the resolution of satellite-derived free-air anomalies is $\sim 15 \mathrm{~km}$ ); (3) existence of a conjugate feature; (4) offset of magnetic anomaly picks.

[18] This process produced a set of $288 \mathrm{FZ}$ picks from 21 separate FZs. We also made a smaller set of 28 picks of 


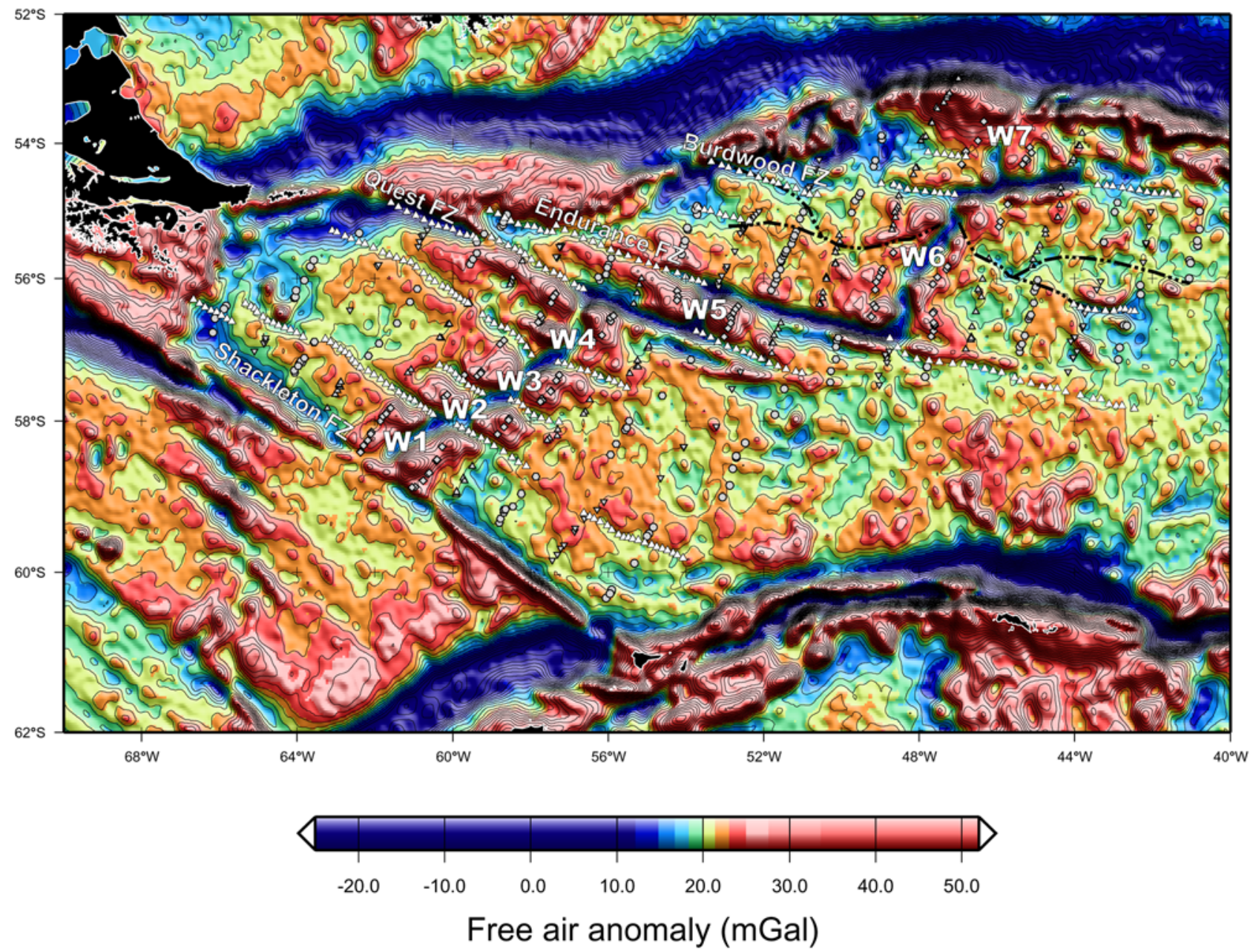

Figure 4. Satellite-derived free-air gravity anomalies [Sandwell and Smith, 1997]. Areas marked W1-W7 indicate spreading corridors described in text. White triangle symbols indicate picks of FZ troughs used in the inversion. Black dash-dotted lines indicate possible offset traces in W6 (see text). Other symbols represent magnetic anomaly picks (see Figures $3 a-3 b$ for key). Contour interval is $20 \mathrm{mGal}$.

fossil transform fault troughs that have some influence on the solution for the youngest rotation.

\subsection{Data Uncertainty}

[19] Positional uncertainty in the data gives rise to uncertainty in the solution that can be illustrated as elliptical confidence regions. The small uncertainties $(<1 \mathrm{~km})$ in the positions of isochron picks due to anomaly skewness at this latitude are not important at the resolution of our study. The calculated uncertainty in the on-screen digitizing process is also negligible. The principal sources of uncertainty in isochron picks have been suggested as navigational uncertainty [Kirkwood et al., 1999], uncertainties in knowledge of the location of a magnetometer with respect to a ship's GPS receiver, and uncertainty in identifying isochrons precisely on magnetic profiles [Gaina et al., 1998]. Eagles [2000] suggested average navigational uncertainty of between $4.4 \mathrm{~km}$ and $6.7 \mathrm{~km}$ in the Scotia Sea, the range depending on different published estimates of the accuracy of Transit satellite fixes. Uncertainties based on difficulty in interpreting along-track anomalies and magnetometerreceiver spacing were put in the region of $2.5-3.5 \mathrm{~km}$ in the intermediate-to-slow spreading rate Tasman Sea [Gaina et al., 1998]. Eagles [2003] concluded that the $\sim 3 \mathrm{~km}$ standard deviation of isochron misfits in an inversion of the neighboring Antarctic-Phoenix spreading system indicated that the identification of magnetic anomalies on profiles is the dominating factor contributing to uncertainty there. The inversion technique here also adopts the standard deviation of its isochron misfits as a measure of their uncertainty $(\sim 5.7 \mathrm{~km})$. This value falls within the range of estimates of navigational uncertainty given above, but is also consistent with increased identification uncertainty in magnetic profiles over crust produced at slower spreading rates in the west Scotia Sea than in the Antarctic-Phoenix spreading system. Müller et al. [1991] suggested a positioning uncertainty in satellite gravity anomalies of $\pm \sim 5 \mathrm{~km}$ after a comparison of troughs in those data with precisely navigated bathymetric data, although this value may be less in the newer satellite gravity compilations that have become available since that study [e.g., Sandwell and Smith, 1997]. An error, of less than $2 \mathrm{~km}$, may occur because of the consistent interpretation of gravity anomaly troughs as the axes of long-offset FZs [Driscoll and 


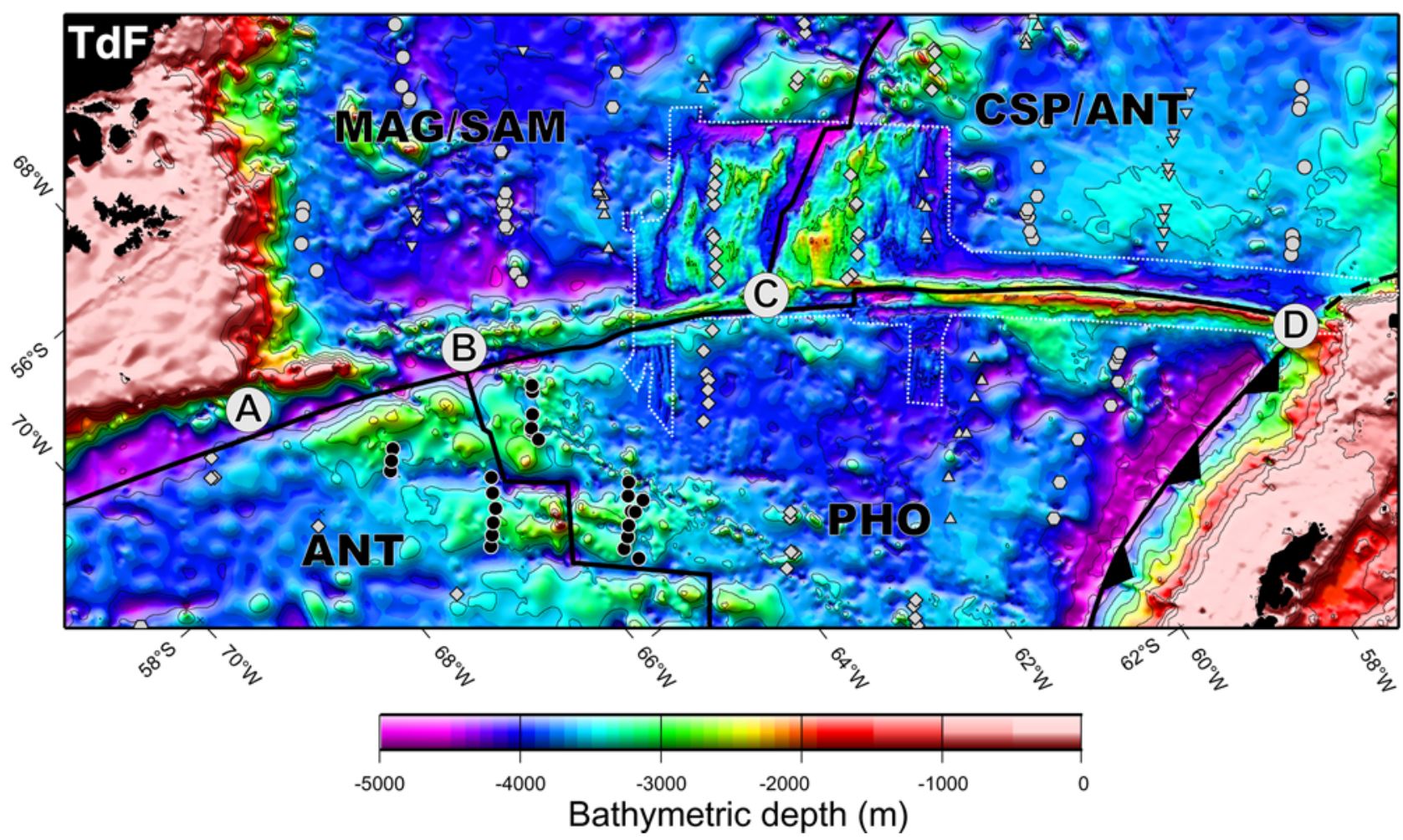

Figure 5. The Shackleton FZ. Bathymetry predicted from satellite altimetry and ship soundings [Smith and Sandwell, 1997] with swath bathymetry [Maldonado et al., 2000; Livermore et al., 2004] inside the white dotted outline. Contour interval is $500 \mathrm{~m}$. Abbreviations are as follows: ANT, Antarctica plate; CSP, Central Scotia Plate; MAG, Magallanes plate; PHO, Phoenix plate; TdF, Tierra del Fuego. Black lines show possible plate boundaries, between the labeled plates. For descriptions of points A-D see text. Magnetic anomaly symbols are used as in Figures $3 a-3 b$, plus black circles, which indicate anomaly $\mathrm{C} 3 \mathrm{~A}$ in the Antarctic-Phoenix system.

Parsons, 1988], but this is unlikely to be of great influence because of its small size and systematic occurrence along flow lines.

\subsection{Results}

[20] We used conjugate-only sets of isochrons, because nearly all the corridors exhibit a full set of isochrons, and because of the undesirable effect that spreading asymmetry would have on an inversion that involved nonconjugate fits. Alternative inversions used data sets including all FZ data, only long-offset FZ data, and only short-offset FZ data, but the differences between the sets of results were not significant. Across-axis strain at the Endurance and Quest transforms is therefore likely to have been minor and/or have occurred after extinction. Here, we only present results from our use of the full FZ data set shown in Figure 4.

[21] We used unweighted data to approach a solution that satisfied all data, and then introduced weighting considerations in order to refine the solution. The weighting process is simple in this conjugate-only exercise and is intended to remove the undue influences of fits to sparse populations of magnetic data by giving more weight to isochrons defined from larger numbers of picks. Data from flow lines with large overall RMS misfits are also given less weight. We tried a number of different starting sets of rotation parameters to check for local minima, and found two minima for
C5: one for a pole situated north of the poles for the pre-C5 rotations, and one for a pole south of them. We present the more southerly solution pole for C5 (Table 1 and Figure 6), and prefer it because it involves a smaller shift in the stage pole progression.

[22] Figure 7 is a visual representation of the fits produced by the model. Figure 7 shows that model flow lines about the solution are a good fit overall to the set of FZs picked. This includes the post-C5, rotated, parts of the FZs that are consistent with the late clockwise rotation of the median valley, as shown by the shift of the $\mathrm{C} 5$ finite pole to the South (Figure 6). In general, the model flow lines faithfully reproduce the FZs picked in free-air gravity data. In the case of a pair of "stranded" FZs in corridor W1, the model shows them to have formed at a single ancient offset by tracking their traces to opposing points on the flanks of the extinct median valley. The poor fits to the deep trough east of the Burdwood FZ are consistent with its apparently transtensional nature.

[23] The set of fits to isochron data in Figure 7 is also reasonably successful. There is often an azimuthal discrepancy close to the Shackleton FZ. A similar effect was observed for anomaly $\mathrm{C} 3$ on the southwest flank of the Shackleton FZ [Eagles, 2003], and is likely to be related to strike-slip deformation at the Shackleton FZ, which can also be seen as rotated abyssal hill fabric in multibeam bathymetric data [Livermore et al., 2000]. Fits of anomalies C8 
Table 1. Solution Finite Rotations for the West Scotia Sea Inversion: Reconstruction for the Period Between the Named Chron and Extinction Around $\mathrm{C} 3 \mathrm{~A}^{\mathrm{a}}$

\begin{tabular}{lcccccccc}
\hline & & & & & \multicolumn{4}{c}{$95 \%$ Ellipsoid } \\
\cline { 6 - 9 } Chron & Age, Ma & Latitude & Longitude & Angle & Axis 1 & Axis 2 & Axis 3 & Azimuth \\
\hline C5 & 10.95 & 6.21 & -27.89 & 0.97 & 5.78 & 0.42 & 0.007 & 74.78 \\
C5C & 16.73 & 31.71 & -23.37 & 2.16 & 3.27 & 0.29 & 0.006 & 73.52 \\
C6 & 20.13 & 37.89 & -23.64 & 3.60 & 2.24 & 0.21 & 0.007 & 73.58 \\
C6B & 23.07 & 31.76 & -27.49 & 5.00 & 1.45 & 0.13 & 0.008 & 75.51 \\
C8 & 26.55 & 17.21 & -32.12 & 6.64 & 1.70 & 0.13 & 0.009 & 77.16 \\
\hline
\end{tabular}

${ }^{\text {a }}$ Rotations are right-handed and describe motion of the northwest flank with respect to the southeast flank. Axes 1 and 2 describe variation in the position of the pole, mostly within the surface of the model sphere; axis 3 is for the rotation angle. All axes measurements are in great circle degrees/2.79, and the azimuth is that of axis 1 , in degrees counterclockwise from east. These parameters describe the 3-D ellipsoid; however, for simplicity only 2-D ellipses are shown in Figure 6.

and C6B were not possible in northern W6 because of their partial or complete absence from the Magallanes flank, where Davis Bank is present instead. The model flow lines suggest that the conjugates to anomaly $\mathrm{C} 8$ identified in northern W6 on the Central Scotia flank should be present between $52^{\circ} \mathrm{W}$ and $51^{\circ} \mathrm{W}$ beneath a deep linear gravity low that dissects northeastern Davis Bank (Figure 4). It is possible, therefore, that parts of Davis Bank have been transported onto the oceanic crust of the west Scotia Sea after chrons $\mathrm{C} 8-\mathrm{C} 6 \mathrm{~B}$.

[24] The 95\% confidence regions in Figure 6 and Table 1 are derived from a covariance matrix defined within the inversion. This covariance matrix is less completely defined than that in the widely used technique of Hellinger [1981], because not all of the magnetic isochron data simultaneously rotate for a best fit. The validity of the covariance matrix in this application depends on three assumptions: firstly that the distributions of residuals on the separate plates are similar and, secondly, normally distributed, and thirdly that the estimated data uncertainties are appropriate [Shaw and Cande, 1990; Wilson, 1993]. The first assumption is likely to be true for the gridded free-air anomalies and for the dense network of magnetic profiles in the west Scotia Sea. Like Shaw and Cande [1990] we try to ensure a normal distribution of residuals with a suitable uncertainty value (second and third assumptions) by defining cutoff criteria to exclude the anomalous tails of the residual distributions that show up in quantile-quantile plots of the residuals (Figure 8). In this way, we excluded isochron data with residuals exceeding one standard deviation (34\% of the isochron data) and FZ data exceeding three standard deviations ( $1 \%$ of the FZ data) when refining the solution and calculating the confidence regions. The standard deviations of the sets of residuals of all isochron data $(5.7 \mathrm{~km})$ and all FZ data $(3.7 \mathrm{~km})$ are used as estimates of the data uncertainty in calculating the confidence regions. All of the FZ data plots approximate straight lines with a gradient of $3.7 \mathrm{~km}$, implying that the second and third assumptions were both appropriate for these data. The plots for magnetic data at C6 and C6B show inflections that indicate some of the data disrupt the normal distribution of the majority. The plot for C8 appears to have a shallower gradient, which means that the $5.7 \mathrm{~km}$ uncertainty value was inappropriate for $\mathrm{C} 8$. It is therefore possible that the confidence regions shown for the $\mathrm{C} 8, \mathrm{C} 6 \mathrm{~B}$ and $\mathrm{C} 6$ rotations are inaccurate estimates although, given the small number of anomalous data and

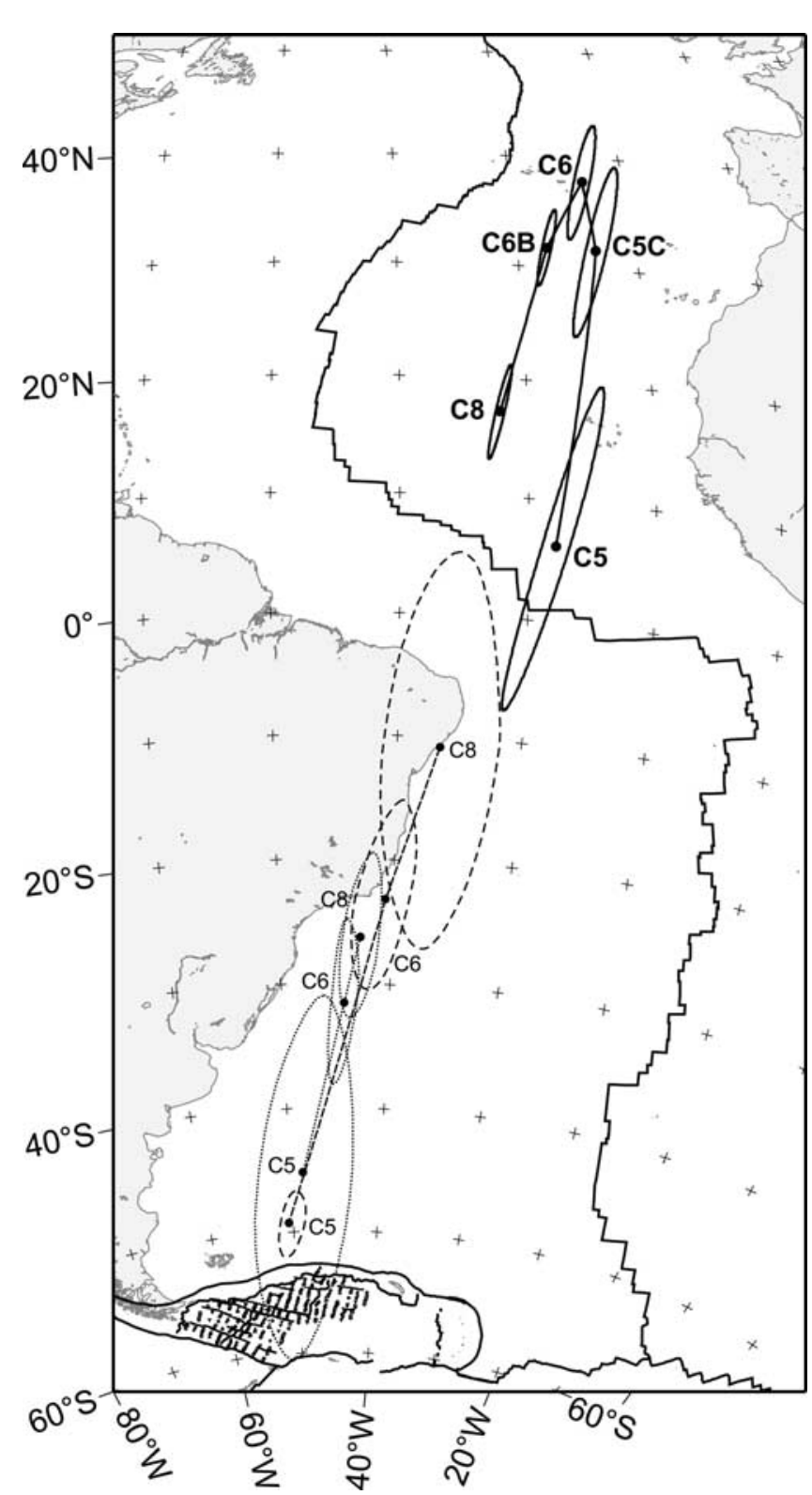

Figure 6. Reconstruction poles and 2-D 95\% confidence ellipses for the west Scotia Sea inversion (solid lines and ellipses). Burrell's [1983] poles and ellipses are also shown: dashed, two-plate model; dotted, three plates. 


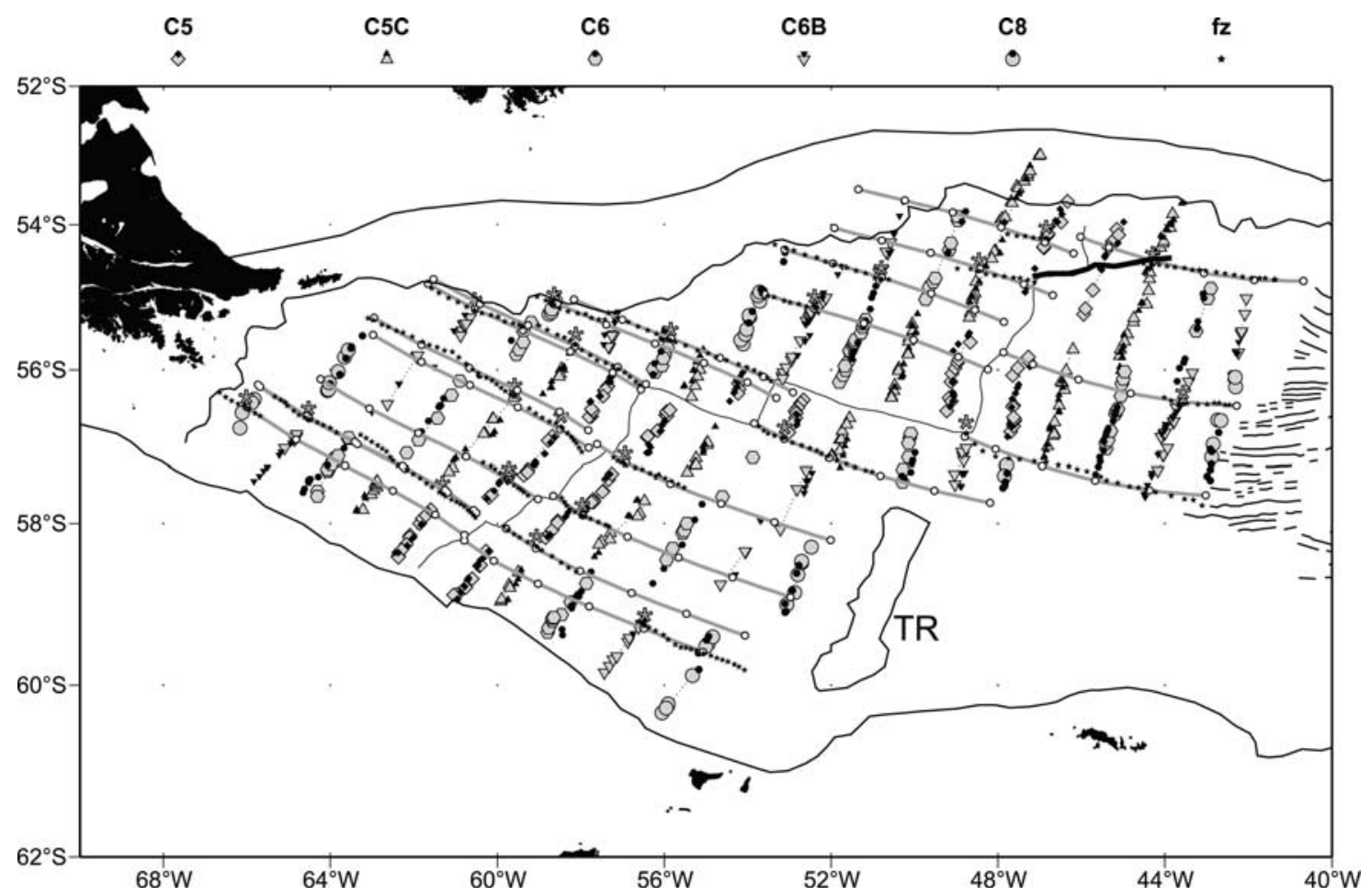

Figure 7. Fits of model elements and data. Lines and symbols are as follows: thick gray lines, model flow lines, with open circles at reconstruction chrons; gray asterisks, "seed" chrons from which model flow lines are grown; small black stars, FZ pick data; large gray symbols, isochron pick data; dotted black lines, great circle segments defined as targets for the rotating isochron data; small dark symbols, rotated isochron picks; thick black line, deep trough east of the Burdwood FZ. TR is Terror Rise.

the high degree of correlation in the flow line data set, the inaccuracy may be small [cf. Eagles, 2003].

[25] Figure 9 illustrates relative data importances for the stability of the solution [Minster et al., 1974]. The FZ data generally have moderate importances. The isochron data importances are individually more variable, although their overall distribution is relatively homogenous, with a tendency to slightly higher importances in the more densely populated spreading corridors. The importances are calculated for data in the final data set, after applying the cutoff criteria. Comparing Figure 7 (where all data appear) with Figure 9 shows that the excluded data are generally magnetic data from isochrons defined by small numbers of picks, and their conjugates, and this indicates that the weighting considerations outlined above have worked effectively. Given this, we conclude that the solution is a reasonable representation of the isochron data set, and hence also of spreading in the west Scotia Sea.

\section{West Scotia Sea and Its Neighbors}

[26] The inversion results suggest that the entire west Scotia Sea was a two-plate system after chron C6 because reasonable fits to the magnetic data for this and younger anomalies can be made in all corridors with a single set of reconstruction rotations, while the non flow line-oriented deep trough east of the Burdwood FZ can be shown not to have formed at a simple ridge-offset transform fault. Hence, after C6, the West Scotia Ridge could only have terminated at triple junctions or transform faults on the Shackleton FZ and/or North Scotia Ridge. There are no high amplitude magnetic anomalies marginward of anomaly C6 in segment W7, suggesting that seafloor spreading did not start there until around chron C6, and so the two-plate system is likely to have been confined to corridors $\mathrm{W} 1-\mathrm{W} 6$ before then. In this interpretation, a triple junction or transform fault existed at the northern edge of W6 until chron C6, and migrated northward with the formation of segment W7.

[27] It is possible to examine the range of possible movements that the Magallanes and Central Scotia plates could have adopted within the South America-West Scotia Sea-Antarctica-Phoenix plate circuit. The possible loci for plate boundaries accommodating these movements are the North Scotia Ridge, South Scotia Ridge and Shackleton FZ, where the Central Scotia and Magallanes plates bordered the South America, Antarctica, and Phoenix plates. We predict relative plate motion at these plate boundaries using the parameters given in Tables 1 and 2 [Nankivell, 1997], and by Eagles [2003]. Figure 10 shows two end-member plate circuits: one in which the Magallanes plate is fixed to South America (i.e., motion only occurred in the South Scotia Ridge region) and one in which the Central Scotia plate is fixed to Antarctica (i.e., motion only occurred on the North Scotia Ridge and Magallanes fault zone). Figure 11 summarizes the predicted motions for these two cases as sets of flow lines. The flow lines are for total movement of one plate with respect to another, and not for a ridge axis with respect to its bounding plates, like those in Figure 7, and hence are useful to predict end-member motions on the North Scotia Ridge and South Scotia Ridge/Shackleton FZ. 

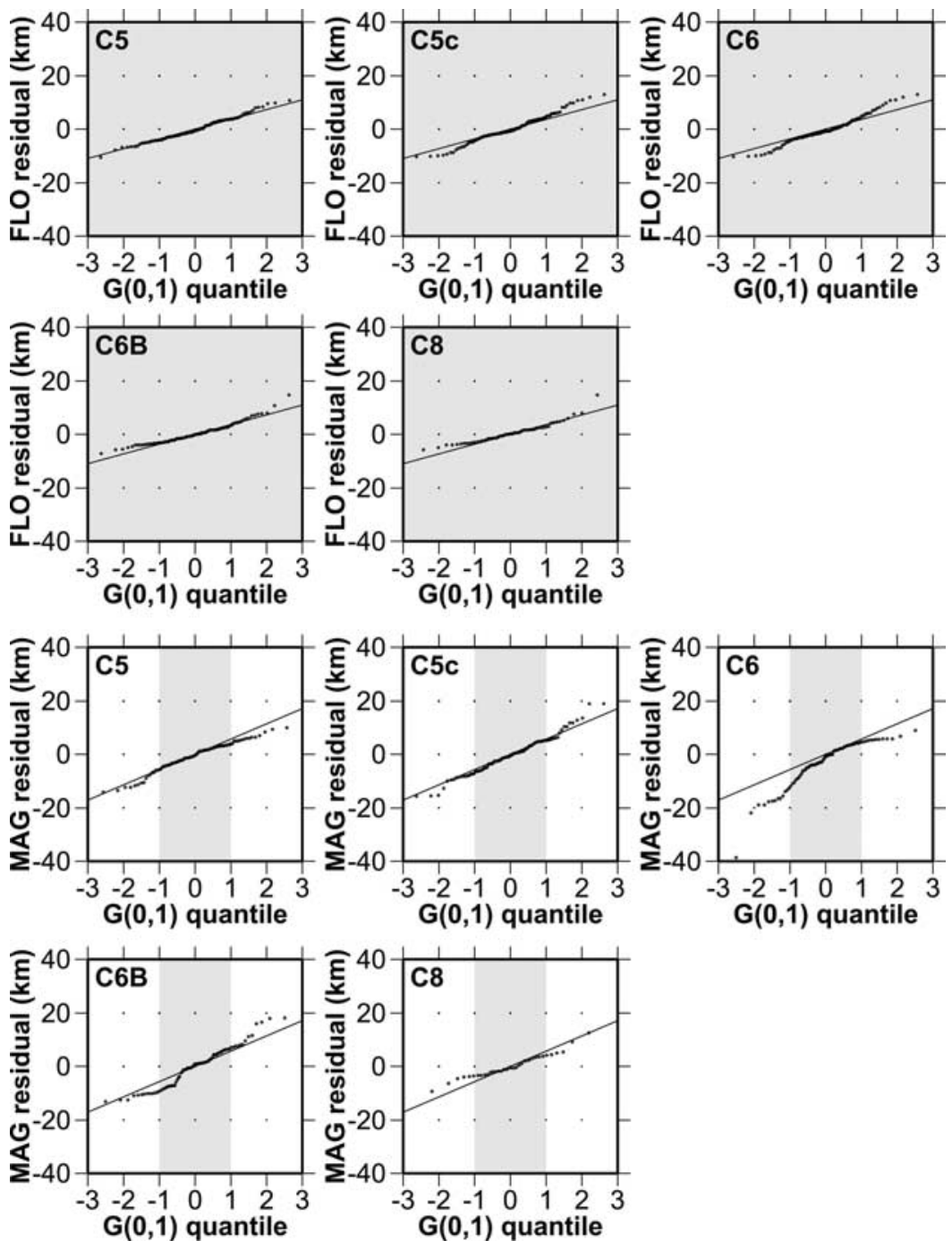

Figure 8. Quantile-quantile plots of residuals to the FZ (FLO) and isochron (MAG) data used in the inversion. Shading indicates limits of the cutoff criteria; data from outside the shaded regions did not contribute to the calculation of the solution statistics. Straight lines indicate how normally distributed populations of data, with uncertainties the same as those adopted in the inversion, would plot.

[28] We estimate that the uncertainties in the rotated points on the flow lines may be as large as $10-30 \mathrm{~km}$, although it is not possible to calculate formal uncertainty regions for the rotated locations on the flow lines, owing to the different anomalies here and in the inversion for South America-Antarctica rotations. It would be inappropriate to address the detailed features of the flow lines for this reason. However, a significant bend in the flow lines results from the combination of a change of spreading azimuth in the South America-Antarctica system after C6y (19.05 Ma) and the spreading rate reduction at the West Scotia Ridge, around $\mathrm{C} 5 \mathrm{D} / \mathrm{C} 5 \mathrm{C}(17.5-16.7 \mathrm{Ma})$. Given their proximity in time, it is possible that these model events have a causal relationship. Whether or not this is the case, we feel it is appropriate to separate our analysis for times before and after the bend.

[29] Barker [2001] published a superficially similar analysis of flow lines for parts of the Scotia Sea with respect to the South America plate that were made using a set of paper-based reconstructions of the Scotia Sea, including the West Scotia Ridge study by Barker and Burrell [1977]. The reconstruction in that particular study has already been shown to have significant inaccuracies and, furthermore, the method used means that it is impossible for the flow lines to have been made using an explicit assumption of circuit closure. Because of this, it is neither possible nor appropriate to make any complete or detailed comparison with our set of flow lines.

\subsection{Fixed Central Scotia Plate}

[30] The end-member in which the Central Scotia plate is assumed fixed to Antarctica predicts $\sim 200 \mathrm{~km}$ of Magallanes plate motion with respect to South America between chrons $\mathrm{C} 8$ and $\mathrm{C} 6 / \mathrm{C} 5 \mathrm{C}$, oriented WSW near Aurora Bank and WNW in Tierra del Fuego, followed by $\sim 150 \mathrm{~km}$ of northeast oriented movement until C3A (Figure 11a). Assuming the plate boundary was confined to the North Scotia Ridge/Falkland Trough and Magallanes 


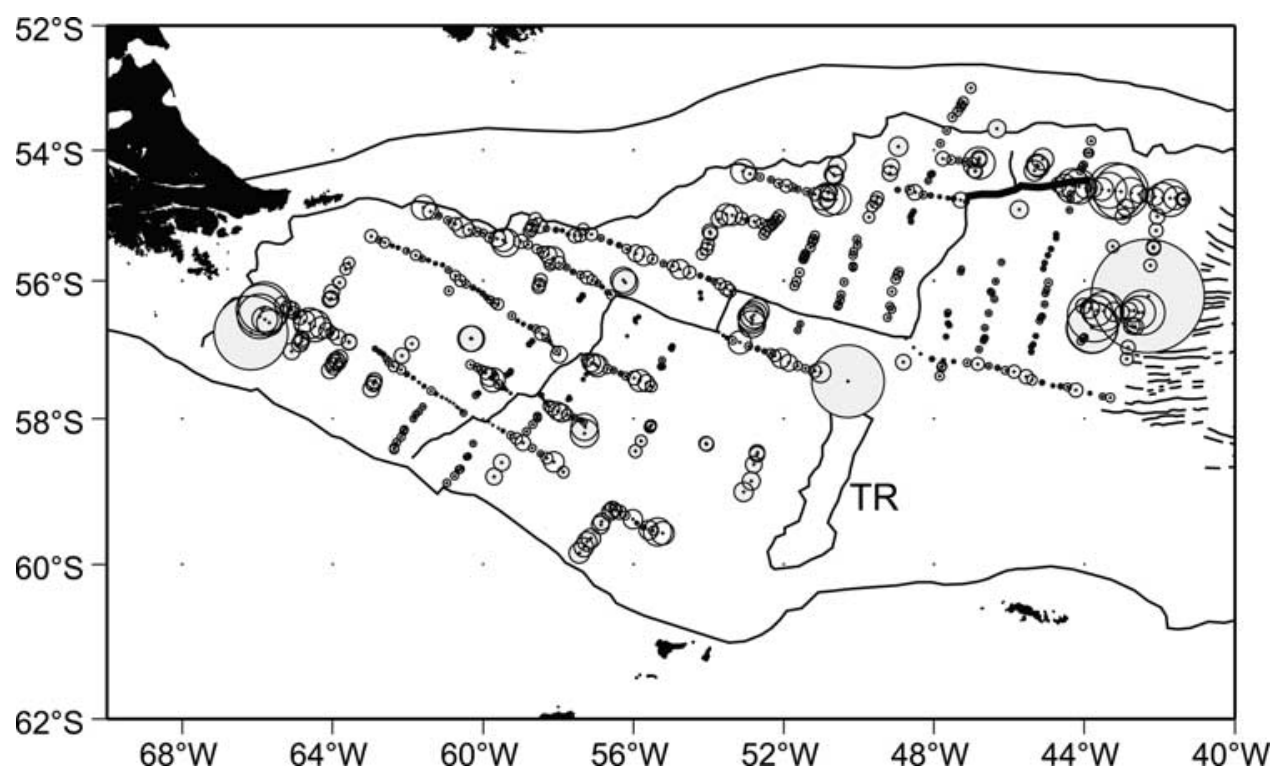

Figure 9. Data importances to the solution. Solid circles indicate isochron data; open circles indicate FZ data. Each circle's area is proportional to the importance of the pick at its center to the stability of the solution. TR is Terror Rise.

fault, these predictions imply dominantly dextral strike-slip movements until $\mathrm{C} 5 \mathrm{C}$, followed by oblique convergence until $\mathrm{C} 3 \mathrm{~A}$.

[31] There is evidence for a long history of north directed convergent deformation in Tierra del Fuego, but not for any phase of primary dextral strike-slip deformation [Klepeis, 1994a, 1994b; Klepeis and Austin, 1997; Kraemer, 2003]. Kraemer [2003] suggests, in a study of the regional structural geology, that the most recent, Neogene, convergent structures in Tierra del Fuego formed during $80 \mathrm{~km}$ of shortening that ended by Plio-Pleistocene times. Similarly, Klepeis [1994b] shows a balanced cross section made with approximately $100 \mathrm{~km}$ of northeast directed shortening for the Deseado thrust fault just to the north of the main Magallanes fault zone. Further east, the North Scotia Ridge west of Aurora Bank consists of a large sediment prism accumulated and deformed against the continental buttress of the Falkland Plateau at a plate boundary situated within the Falkland Trough [Ewing et al., 1971; Ludwig et al., 1978; Ludwig and Rabinowitz, 1982; Ludwig, 1983; Lorenzo and Mutter, 1988; Bry et al., 2004]. Large reverse faults in the prism and foreland basin terminate at or just below the present day seafloor but recent sediments, which occur only in localized drifts, are undeformed, suggesting that convergence has quite recently ceased [Cunningham et al., 1998; Cunningham, 1998]. There are no published estimates of the precise azimuth or amount of convergence at the North Scotia Ridge. Our prediction and the published observations of convergence provide a plausible explanation for the obscuration of preC6 seafloor spreading anomalies by thrusting beneath Davis bank. These observations can be accommodated within our predicted $\sim 150 \mathrm{~km}$ of C6-C3A (mid-Miocene to latest Miocene) convergence at the Magallanes-South America plate boundary, but permit the possibility of contemporaneous movements on the South Scotia Ridge as well.
[32] East of Aurora Bank, the assumption of a Central Scotia plate fixed to Antarctica requires that the eastern North Scotia Ridge accommodated movements identical to South America-Antarctica relative motions, that is, Antarctica moving ESE until C6 $(\sim 160 \mathrm{~km})$ and afterward eastward $(\sim 270 \mathrm{~km})$. The path of the plate boundary taking up these movements would have been dependent on the site of northern termination of the West Scotia Ridge. The northernmost parts of segment W7 may only have existed since the West Scotia Ridge propagated northward some time after C6, based on the identifiable magnetic anomalies there and the high-frequency magnetic anomalies beneath Aurora Bank (Figures 3a-3b). After this propagation, therefore, it is likely that the plate boundary followed the ESE and east trending axis of the Falkland Trough north of Shag Rocks and South Georgia. Our predicted post-C6/C5C movements would have produced sinistral strike-slip and transpressional deformation there. Ludwig and Rabinowitz [1982] show that evidence for convergent deformation in seismic data crossing the North Scotia Ridge is more subdued north of Shag Rocks than it is north of Burdwood Bank, and that it may even be absent north of South Georgia. An analysis of acoustic backscatter fabric in GLORIA data, by Cunningham et al. [1998], similarly identifies different convergent deformation structures north

Table 2. Finite Rotations for Relative South America-Antarctica Plate Movements During the Time Period the West Scotia Ridge was Active ${ }^{\mathrm{a}}$

\begin{tabular}{lcccc}
\hline Chron & Age, Ma & Latitude & Longitude & Angle \\
\hline C2A & 2.58 & 72.25 & -26.48 & 0.60 \\
C5y & 9.74 & 78.60 & -32.21 & 2.47 \\
C6y & 19.05 & 85.88 & -33.56 & 6.79 \\
C8y & 25.82 & 73.48 & -14.73 & 7.35 \\
C13y & 33.06 & 75.11 & -7.39 & 10.26 \\
\hline
\end{tabular}

${ }^{\mathrm{a}}$ Taken from Nankivell [1997]. 

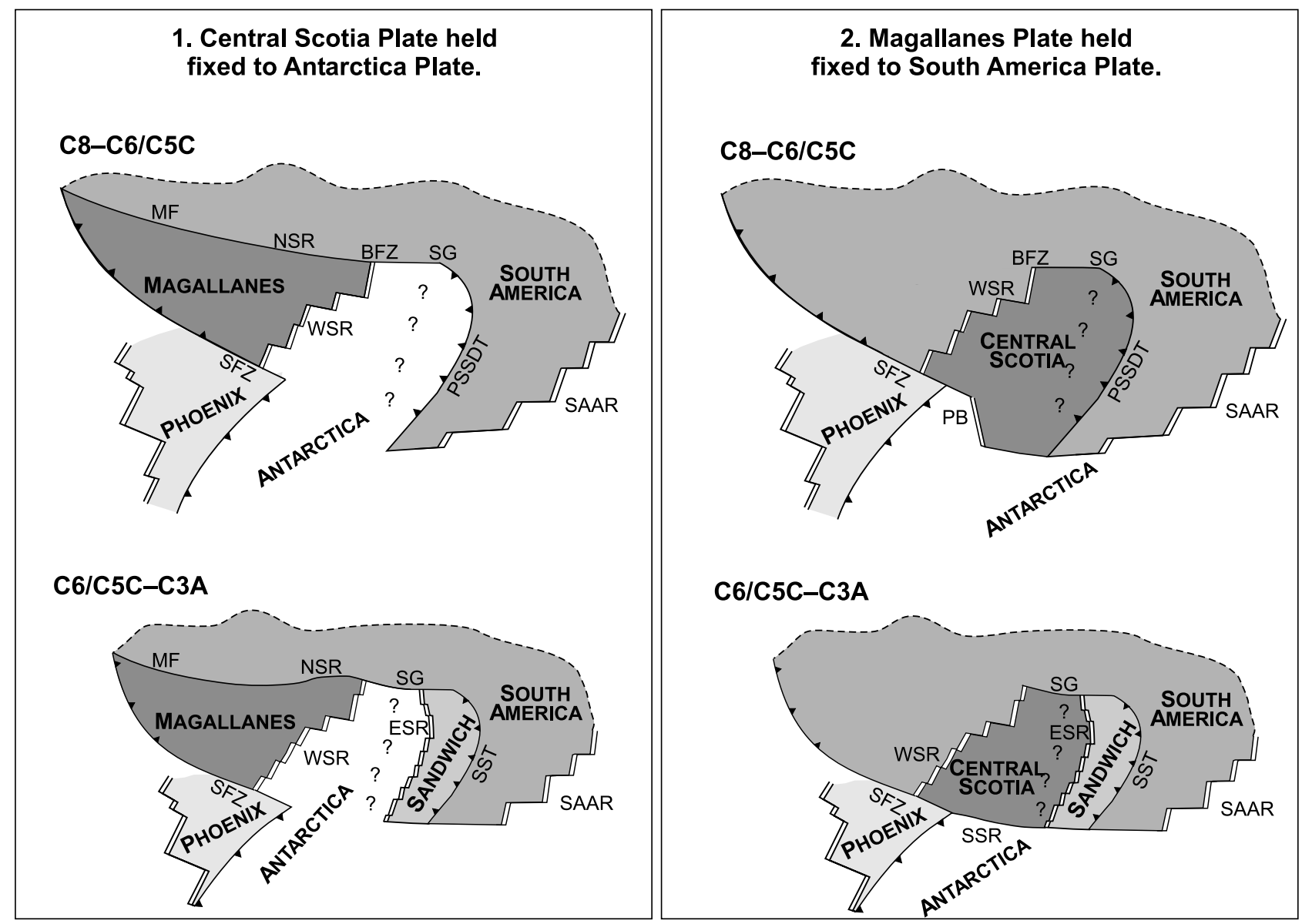

Figure 10. Cartoons illustrating two possible closed plate circuits involving the west Scotia Sea, South America, Antarctica and Phoenix plates. Plates are identified by shading and labels in bold type. Abbreviations are as follows: BFZ, Burdwood Fracture Zone; ESR, East Scotia Ridge; MF, Magallanes Fault; NSR, North Scotia Ridge; PB, Powell Basin; PSSDT, proto-South Sandwich-Discovery Trench; SAAR, South American-Antarctic Ridge; SFZ, Shackleton Fracture Zone; SG, South Georgia; SSR, South Scotia Ridge; SST, South Sandwich Trench; WSR, West Scotia Ridge. Question marks indicate possible plate boundaries in the central Scotia Sea, Dove and Protector Basins not considered in this analysis.

of Shag Rocks than further west. These observations are consistent with our suggestion of oblique convergence (Magallanes-South America) in the west, and transpression (South America-Antarctica) in the east, of the North Scotia Ridge during the $\mathrm{C} 6 / \mathrm{C} 5 \mathrm{C}-\mathrm{C} 3 \mathrm{~A}$ period.

[33] Before the West Scotia Ridge propagated northward at around chron $\mathrm{C} 6$, it would have terminated in segment W6 and a South America-Antarctica plate boundary would have run along the eastern conjugate to the Burdwood FZ and possibly then through Shag Rocks and South Georgia (Figure 11a). The left-lateral ESE trending offsets between South Georgia and Shag Rocks, of the South Georgia microcontinent's bathymetric outline, and between outcrops of the Cretaceous Drygalski Fjord Complex on South Georgia and Clerke Rocks [Storey and Macdonald, 1984] may mark this plate boundary zone. Faults marking the offsets would have responded to the predicted pre-C6 South America-Antarctica motion with sinistral transtensional tectonics. The offset of the SE striking Drygalski Fjord complex is $\sim 80 \mathrm{~km}$, meaning that deformation must have been distributed on more than one fault zone to be consistent with our predicted $\sim 160 \mathrm{~km}$ of total relative plate motion before C6.

\subsection{Fixed Magallanes Plate}

[34] Holding the Magallanes plate fixed to South America predicts Central Scotia plate motion with respect to Antarctica of $\sim 250 \mathrm{~km}$ to the east between $\mathrm{C} 8$ and $\mathrm{C} 6 / \mathrm{C} 5 \mathrm{C}$, followed by $\sim 120 \mathrm{~km}$ to the south until C3A (Figure 11b). When imagining what this might have meant for tectonics at the Shackleton FZ and South Scotia Ridge, it is important to consider that the present day plate boundary through the South Scotia Ridge probably only dates from the time of the most recent ridge-crest-trench collisions ( $\sim \mathrm{C} 5$ to $\mathrm{C} 3$ ) at Discovery Bank near its eastern end [Barker et al., 1982; Hamilton, 1989]. As a result of these collisions, and similar earlier collisions, the former Central Scotia-Antarctica boundary would have stepped northward in order to track the southern tip of the protoSouth Sandwich-Discovery Trench. On the basis of the distribution of FZs and magnetic anomaly sequences in the Weddell Sea, this trench probably originally reached 

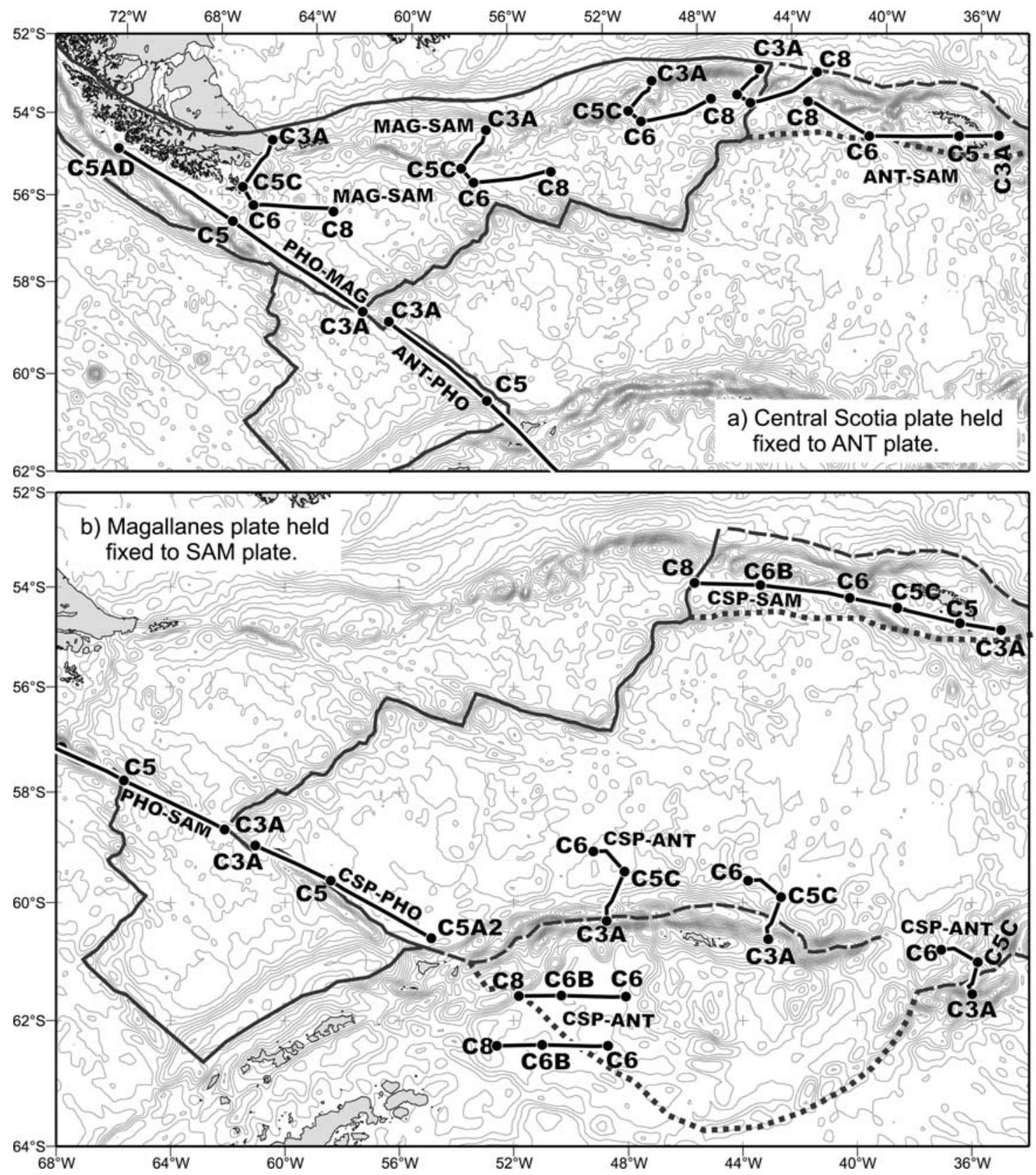

Figure 11. Predicted flow lines for west Scotia Sea plates with respect to surrounding plates, overlaid on contours of the present-day satellite-derived free-air gravity anomaly field [Sandwell and Smith, 1997]. Heavy gray lines indicate plate boundaries; dashed gray lines indicate younger alternative plate boundaries; dotted gray lines indicate older alternatives (see text); black lines indicate flow lines; black points indicate selected chrons. Flow lines are annotated according to plate pair: The first named plate moves relative to the second. Abbreviations are as follows: ANT, Antarctica plate; CSP, Central Scotia plate; MAG, Magallanes plate; PHO, Phoenix plate; SAM, South America plate.

as far as the southeastern corner of the South Orkney Microcontinent.

[35] The extinct spreading center in Powell Basin, which is thought to have been active during part of the period of West Scotia Ridge spreading [King and Barker, 1988; Lawver et al., 1992; King et al., 1997; Eagles and Livermore, 2002; Lawver and Gahagan, 2003], provides a reasonable path for a plate boundary connecting the West Scotia Ridge to this point southeast of the South
Orkney Microcontinent, via the Shackleton FZ. Eagles and Livermore [2002] suggested that the basin contains $\sim 240 \mathrm{~km}$ of oceanic crust created by ENE directed spreading, based on low-amplitude magnetic anomalies and the disposition of two strongly negative marginal free-air gravity anomalies interpreted as representing rift basins. The $\sim 250 \mathrm{~km}$ of predicted Central Scotia-Antarctica movement between chrons C8 and C6 is closely comparable to this estimate, although the flow line is directed east, and 


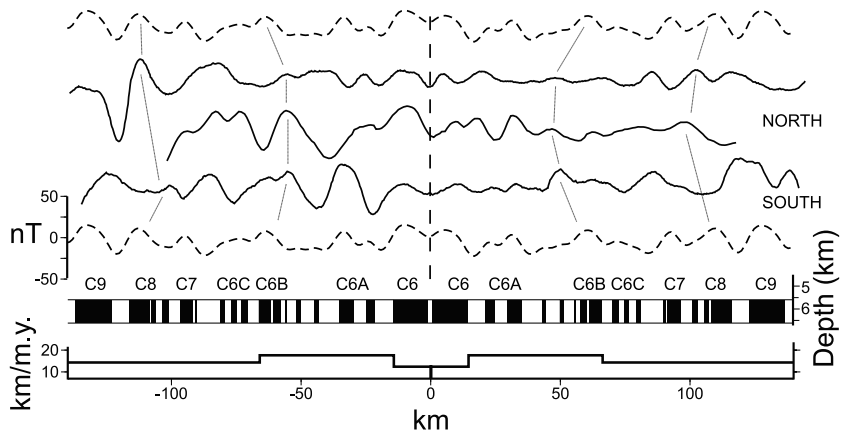

Figure 12. Model spreading (dashed line) compared to three USAC aeromagnetic profiles (continuous lines) over Powell Basin [Eagles and Livermore, 2002]. The model uses spreading rates predicted from movements between the Central Scotia and Antarctica plates, assuming no movement on the North Scotia Ridge, and ceases spreading at $18.98 \mathrm{Ma}$. Note the very low amplitudes [King et al., 1997]. The profiles are projected onto $085^{\circ}$ and centered on the axial gravity low in Powell Basin. Model created with an effective susceptibility of 0.0016 magnetizing a $1 \mathrm{~km}$ thick flat source layer at $5.6 \mathrm{~km}$ depth.

not slightly north of east. Various possibilities may be considered to explain the slight disagreement between the predicted and observed opening directions of Powell Basin: These include the possibility of minor movements on the North Scotia Ridge at this time, the rather large uncertainties in the positions of post-C8 South America-Antarctica finite poles, and the presence of an active Jane-Discovery back-arc basin in the South America-Central Scotia-Antarctica plate circuit. Eagles and Livermore [2002] modeled a low-amplitude set of magnetic anomalies in Powell Basin as a sequence of anomalies from $\mathrm{C} 11$ to $\mathrm{C} 6 \mathrm{AA}$, guided by previous estimates of its age from thermal subsidence considerations [King and Barker, 1988]. The magnetic anomaly identifications were regarded as tentative because of the low amplitudes and incoherency of the waveforms in the aeromagnetic profiles. Figure 12 shows an attempt to model the same magnetic anomalies using spreading rates prescribed by the predicted Central Scotia-Antarctica movements of Figure $11 \mathrm{~b}$ during the $\mathrm{C} 8-\mathrm{C} 6$ period. The model, whose age is also consistent with basement depth in Powell Basin, is a reasonable approximation to the data and there is a suggestion, by extrapolation, that anomaly C9 may appear on some of the profiles, as is the case in the west Scotia Sea.

[36] The C5C-C3A prediction of $\sim 120 \mathrm{~km}$ of south directed movement implies convergence across the later South Scotia Ridge boundary, which would have run north of Powell Basin and the South Orkney Microcontinent. There is no evidence from outcrop geology in the South Orkney Islands for Neogene convergence. In contrast, seismic reflection data hint at fairly recent convergence in the form of an interpreted accretionary prism north of Elephant Island and north of the South Orkney Islands between $50^{\circ} \mathrm{W}$ and $52^{\circ} \mathrm{W}$ [Acosta and Uchupi, 1996; Aldaya and Maldonado, 1996; Lodolo et al., 1997], although this feature is rather small and discontinuous.
There are no estimates for the amount of convergence that might have produced the accretionary prism.

[37] East of W7, our assumption of an independent Central Scotia plate slightly modifies the previous prediction of movements through and north of the South Georgia microcontinent and Shag Rocks parts of the North Scotia Ridge. In this case, the predicted movements are consistently east to ESE directed, and rather faster prior to chron C6/C5C. The offsets of and between the South Georgia microcontinent and Shag Rocks would have responded in a transtensional sense, whereas a transform in the Falkland Trough north of Shag Rocks would have undergone transpression. As shown above, the small amount of data for the region is consistent with these slightly modified predictions.

\subsection{Shackleton Fracture Zone}

[38] It is only possible to predict end-member relative movements at the Shackleton FZ after chron C5AD $(\sim 15 \mathrm{Ma})$, the oldest useable conjugate anomaly pair in the inversion by Eagles [2003]. With the Central Scotia plate held fixed to Antarctica (Figure 11a), predicted Phoenix-Magallanes and Phoenix-Antarctic movements are consistently subparallel to the present-day Shackleton FZ. When the Magallanes plate is held fixed to South America (Figure 11b), the flow line produced for the Phoenix-Central Scotia plate pair is rotated by $11^{\circ}$ and that for the Phoenix-South America pair is rotated by $\sim 5^{\circ}$, both anticlockwise, with respect to the Shackleton FZ. Hence, with the Central Scotia plate fixed to Antarctica, fast sinistral strike-slip movements would have occurred all along the Shackleton FZ at any point during the lifetime of the West Scotia Ridge. In contrast, with the Magallanes plate fixed to South America, strike-slip movements would have had a component of convergence that was greatest in the southeast. This convergent component is consistent with the observation of an oceanic transverse ridge at the southeast end of the Shackleton FZ [Livermore et al., 2004]. Furthermore, if the transverse ridge consists of flexurally uplifted Phoenix plate lithosphere, as those authors argue, it can be dated as having first appeared by estimating the time when that part of the Phoenix plate first encountered the Central Scotia plate, between $11 \mathrm{Ma}$ and $7 \mathrm{Ma}$.

[39] Before and after chron C5AD, the Antarctic-Phoenix plate system opened about similar stage poles [Larter and Barker, 1991; Eagles, 2003], and so it is likely that the tectonic settings implied by the flow lines shown here would have applied since at least the changes within the west Scotia Sea around C5C. Hence it is possible the Phoenix-Central Scotia plate boundary hosted a transverse ridge throughout $\mathrm{C} 5 \mathrm{C}-\mathrm{C} 3 \mathrm{~A}$ times, and that this ridge was continuously undergoing subduction beneath Elephant Island.

\subsection{Synthesis}

[40] The sketches in Figure 13 illustrate the first two stages of our preferred three-stage view of the plate tectonic development of the west Scotia Sea's boundaries with the Antarctica and South America plates.

[41] Before the changes around chrons $\mathrm{C} 6 / \mathrm{C} 5 \mathrm{C}$, our flow lines predict the opening of Powell Basin, and the formation of magnetic anomalies there, as a response to Central 
a) $\mathrm{C} 8-\mathrm{C} 6 / \mathrm{C} 5 \mathrm{C}$

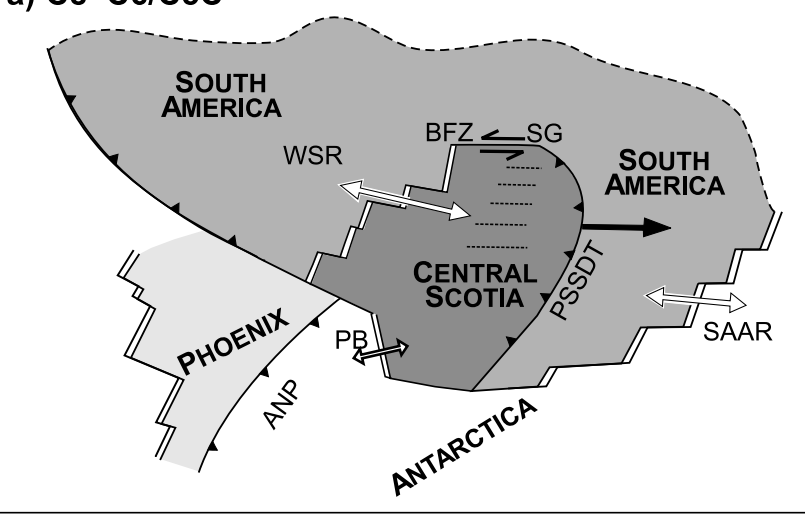

b) $\mathrm{C} 6 / \mathrm{C} 5 \mathrm{C}-\mathrm{C} 3 \mathrm{~A}$

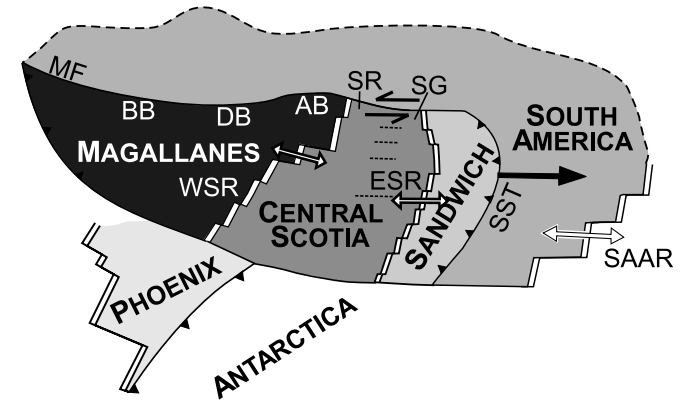

Figure 13. ( $a$ and $b$ ) Cartoons showing hypothetical plate tectonic evolution of the Scotia Sea. Abbreviations are as follows: AB, Aurora Bank; ANP, Antarctica Peninsula; BB, Burdwood Bank; BFZ, Burdwood FZ; DB, Davis Bank; ESR, East Scotia Ridge; MF, Magallanes Fault; PB, Powell Basin; PSSDT, proto-South Sandwich-Discovery Trench; SAAR, South American-Antarctic Ridge; SG, South Georgia; SR, Shag Rocks; SST, South Sandwich Trench. Dotted lines illustrate the position of the east striking magnetic anomalies of the central Scotia Sea if they predate the west Scotia Sea. Thick white arrows illustrate spreading directions.

Scotia-Antarctica plate movements, reasonably well. The alternative prediction of dextral strike-slip deformation at the Magallanes-South America plate boundary in Tierra del Fuego and on the western North Scotia Ridge is not supported by structural and geological indications, although some movement on this boundary cannot be discounted on the basis of the uncertainties in our analysis. Either set of predictions can be consistent with a long transform plate boundary that connected the northern tip of the proto-South Sandwich-Discovery Trench with the ridge crest in W6, although data from this region are too scant to support or deny the existence of this boundary. Hence, in Figure 13a, we show plate boundaries through Powell Basin in the South Scotia Ridge, along the Burdwood FZ, and through eastern parts of the North Scotia Ridge, but no active plate boundary in Tierra del Fuego and the western North Scotia Ridge.

[42] Between chrons $\mathrm{C} 6 / \mathrm{C} 5 \mathrm{C}$ and $\mathrm{C} 3 \mathrm{~A}$ (Figure 13b), predicted convergence at the North Scotia Ridge and/or Shackleton FZ and South Scotia Ridge is consistent with geological and geophysical observations in all those settings, although the evidence suggests that more convergence may have occurred at the North Scotia Ridge than at the South Scotia Ridge. Hence we think that, following the transition at around $\mathrm{C} 6 / \mathrm{C} 5 \mathrm{C}$, the Magallanes plate started to move independently of the South America plate, converging with it, whereas the Central Scotia plate's motion relative to the Antarctica plate slowed significantly, and became convergent. This change permits continuing movement on a long transform plate boundary connecting the East Scotia Ridge axis with the West Scotia Ridge, but by now the West Scotia Ridge had migrated north into W7, consistent, as already shown, with side-scan sonar evidence for transpressional deformation in the Falkland Trough to the north of Shag Rocks.

[43] In the final stage of our model, the Magallanes and Central Scotia plates amalgamate around chron C3A, when spreading ceases at the West Scotia Ridge. This event formed the modern Scotia plate, which is likely to have moved between two sinistral, dominantly strike-slip fault zones on the South Scotia Ridge-Shackleton FZ and North Scotia Ridge-Magallanes fault zone ever since [Klepeis, 1994a; Thomas et al., 2003].

\section{Discussion}

[44] The area between the West Scotia Ridge and the South Sandwich Trench has been interpreted as formed by the opening of four basins since 40 Ma: the central Scotia Sea, Protector Basin, Dove Basin and east Scotia Sea, all of which have been suggested to have been active at the same time as the West Scotia Ridge [e.g., Barker, 1972; Hill and Barker, 1980; Barker, 1995, 2001; Vanneste and Larter, 2002]. It is not possible to apply a similar method to that used for the North Scotia Ridge and South Scotia Ridge in order to investigate plate motions in the region occupied by these basins, because past movements of the South Sandwich Trench are not well known with respect to the global plate circuit. Despite this, a more general consideration of this region, in the light of our inversion results, is possible.

[45] Of the basins, only the east Scotia Sea has been reliably dated; the Dove and Protector basins are too small to yield unequivocal magnetic anomaly sequences [Barker and Hill, 1981], or reliable heat flow or basement depth measurements, and data from the central Scotia Sea are ambiguous [Hill and Barker, 1980; Zlotnicki et al., 1980; Barker and Lawver, 2000]. Magnetic anomaly profiles on the flanks of the East Scotia Ridge show that recent spreading has greatly exceeded relative motion in the South America-Antarctica system. This spreading is a response to the lengthening of the segment of the South AmericaAntarctica boundary occupied by the Scotia Sea, because of the relative westward retreat of the South America plate and eastward rollback of the South Sandwich Trench [Barker, 1972]. Apart from the very slow relative movements at the North Scotia Ridge and South Scotia Ridge, all of the trench movement is balanced by spreading at the East Scotia Ridge between the Scotia and Sandwich plates. Barker [1995] and Vanneste and Larter [2002] interpret magnetic anomalies to show that the East Scotia Ridge is likely to have operated in this way since a spreading rate increase around chron C3A, when the West Scotia Ridge ceased spreading, and that 


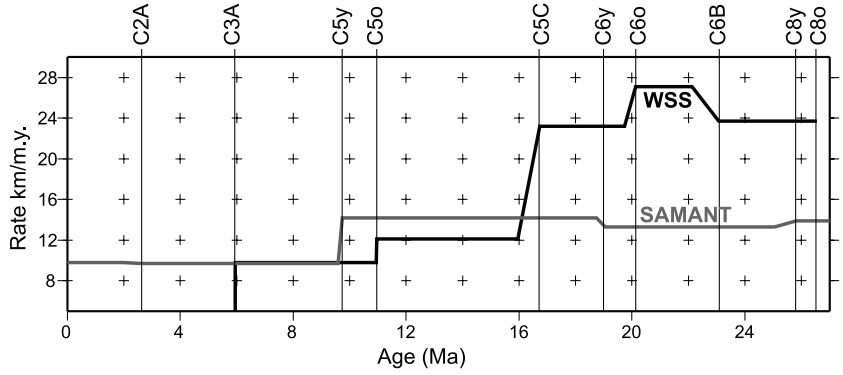

Figure 14. Model spreading rates for West Scotia Ridge (WSS, black line) and South America-Antarctica spreading (SAMANT, gray line; using rotations from Table 2) calculated at $56^{\circ} \mathrm{S}, 57^{\circ} \mathrm{W}$. The South America-Antarctica rotations are for the younger edges (y) of $\mathrm{C} 8, \mathrm{C} 6$, and $\mathrm{C} 5$ and $\mathrm{C} 2 \mathrm{~A}$; the west Scotia Sea ones are for the older edges (o) of $\mathrm{C} 8, \mathrm{C} 6 \mathrm{~B}, \mathrm{C} 6, \mathrm{C} 5 \mathrm{C}$, and $\mathrm{C} 5$.

there was an earlier phase of slower spreading that started some time before chron C5B.

[46] Figure 14 illustrates a comparison between spreading rates calculated at $56^{\circ} \mathrm{S}, 57^{\circ} \mathrm{W}$, within the west Scotia Sea and South America-Antarctica systems, using the results of our inversion and the South America-Antarctica rotation parameters in Table 2. The West Scotia Ridge and South America-Antarctica systems are closely comparable in terms of accretion rate after $\mathrm{C} 5 \mathrm{C}$ but, between anomalies $\mathrm{C} 8$ and $\mathrm{C} 5 \mathrm{C}$, this was much greater at the West Scotia Ridge than in the South America-Antarctica system. Because of this, we think it is very likely that the ancient trench also migrated eastward and that the $\sim 220 \mathrm{~km}$ of extra crust accreted at the West Scotia Ridge before $\mathrm{C} 5 \mathrm{C}$ accommodated this migration. The coincidence in the timing of the drop in West Scotia Ridge spreading rate and of the inception of a back-arc spreading center at the East Scotia Ridge can most simply be interpreted as evidence that the East Scotia Ridge replaced the West Scotia Ridge as the principal site at which eastward rollback of the South Sandwich Trench was accommodated at around C5C. A second coincidence, between extinction of the West Scotia Ridge and the spreading rate increase on the East Scotia Ridge around $\mathrm{C} 3 \mathrm{~A}$, can be interpreted as evidence that the East Scotia Ridge also finally supplanted the West Scotia Ridge as the principal site where relative westward retreat of South America was accommodated.

[47] The simplest explanation for this apparent coupling of the spreading at the West Scotia Ridge and East Scotia Ridge with trench migration and South America-Antarctica motion is that the Central Scotia plate was the sole arc plate between $\mathrm{C} 8$ and about $\mathrm{C} 5 \mathrm{C}$, at which time the Sandwich plate was initiated as its replacement (Figure 13). This is consistent with our diagnosis of the west Scotia Sea as a two-plate system and with the uniform widths and strikes of magnetic anomalies in the east Scotia Sea that suggest it also separated just two plates. The West Scotia Ridge and East Scotia Ridge bounded the western and eastern edges of a single plate-the Central Scotia plate. The alternative, a mosaic of small plates between which the central Scotia Sea, Protector, and Dove basins would have opened if they were active at the same time as the West Scotia Ridge [e.g., Hill and Barker, 1980; Barker and Hill, 1981; Barker, 2001], is, with present data, an unnecessary complication. These plates should have left other evidence for their presence in addition to the equivocal age-data in the basins, but such evidence is difficult to identify or interpret in presently available data sets. In particular, there is no strong evidence for a fossil spreading center in the central Scotia Sea, there are no obvious triple junction traces or fossil transforms that might have connected the spreading center to the North Scotia Ridge or South Scotia Ridge, and it is impossible to identify magnetic bights despite the high density of magnetic profile data (Figures $3 a-3 b$ ).

[48] The hypotheses of post-C 8 spreading in the central Scotia Sea, Dove and Protector basins cannot be invalidated by their complexity or by the absence of clear evidence for the circuit of plate boundaries they defined. However, our alternative model is simpler and does not rely on absence of evidence. In it, the Central Scotia plate, although fulfilling a similar role to the later Sandwich plate, was not created entirely by arc growth and back-arc spreading, but consisted of a preexisting collage of continental blocks and oceanic basins to the east of the west Scotia Sea. The central Scotia Sea, Protector Basin and Dove Basin are parts of this collage, and so must, in this model, be older than chron C8; they need not have opened simultaneously or by back-arc extension. Consistent with this, a very old age for the central Scotia Sea has already been suggested by DeWit [1977]. This view implies the presence of a wide swath of deep water in Drake Passage before chron $\mathrm{C} 8$, instead of the hitherto widely accepted view of a tight arrangement of island-arc and microcontinental fragments [Barker, 2001]. These two fundamentally different paleogeographies for the Drake Passage gateway have very different implications for both regional and global paleobiogeography and paleoceanography.

[49] Acknowledgments. Initial work was funded by NERC award GT22/95/ANT4/3 made under the Antarctic Special Topic. G. E. acknowledges the cooperation of Karsten Gohl, of AWI, on whose German Research Foundation grants GO724/2-1\&2 he was employed while this work developed further. We thank JGR Associate Editor Don Forsyth, who provided a constructive review, and one more critical reviewer who chose to remain anonymous.

\section{References}

Acosta, J., and E. Uchupi (1996), Transtensional tectonics along the South Scotia Ridge, Antarctica, Tectonophysics, 267, 31-56.

Aldaya, F., and A. Maldonado (1996), Tectonics of the triple junction at the southern end of the Shackleton FZ (Antarctic Peninsula), Geo Mar. Lett., 16, 279-286.

Barker, P. F. (1970), Plate tectonics of the Scotia Sea region, Nature, 228, $1293-1296$.

Barker, P. F. (1972), A spreading centre in the east Scotia Sea, Earth Planet. Sci. Lett., 15, 123-132.

Barker, P. F. (1982), The Cenozoic subduction history of the Pacific margin of the Antarctic Peninsula, J. Geol. Soc. London, 139, 787-801.

Barker, P. F. (1995), Tectonic framework of the east Scotia Sea, in Backarc Basins: Tectonics and Magmatism, edited by B. Taylor, pp. 281-314, Springer, New York.

Barker, P. F. (2001), Scotia Sea regional tectonic evolution: Implications for mantle flow and palaeocirculation, Earth Sci. Rev., 55, 1-39.

Barker, P. F., and J. Burrell (1977), The opening of Drake Passage, Mar. Geol., 25, 15-34.

Barker, P. F., and I. A. Hill (1981), Back-arc extension in the Scotia Sea, Philos. Trans. R. Soc. London, Ser. A, 300, 249-262.

Barker, P. F., and L. A. Lawver (2000), Anomalous temperatures in central Scotia Sea sediment-Bottom water variation or pore water circulation in old ocean crust, Geophys. Res. Lett., 27, 13-16. 
Barker, P. F., I. A. Hill, S. D. Weaver, and R. J. Pankhurst (1982), The origin of the eastern South Scotia Ridge as an intraoceanic island arc, in Antarctic Geoscience, edited by C. Craddock, pp. 203-211, Univ. of Wisc. Press, Madison.

Barker, P. F., P. L. Barber, and E. C. King (1984), An early Miocene ridge crest-trench collision on the South Scotia Ridge near $36^{\circ} \mathrm{W}$, Tectonophysics, 102, 315-332.

Barker, P. F., I. W. D. Dalziel, and B. C. Storey (1991), Tectonic development of the Scotia Arc region, in Antarctic Geology, edited by R. J. Tingey, pp. 215-248, Oxford Univ. Press, New York.

Beu, A. G., M. Griffin, and P. A. Maxwell (1997), Opening of Drake Passage gateway and late Miocene to Pleistocene cooling reflected in Southern Ocean molluscan dispersal: Evidence from New Zealand and Argentina, Tectonophysics, 281, 83-97.

British Antarctic Survey (1985), Tectonic map of the Scotia arc 1:3000000 BAS (Misc.) Cambridge, UK.

Bry, M., N. White, S. Singh, R. England, and C. Trowell (2004), Anatomy and formation of oblique continental collision: South Falkland basin, Tectonics, 23, TC4011, doi:10.1029/2002TC001482.

Burrell, J. (1983), The evolution of Drake Passage, Ph.D. thesis, Univ. of Birmingham, Birmingham, UK.

Cande, S. C., and D. V. Kent (1995), Revised calibration of the geomagnetic polarity time scale for the late Cretaceous and Cenozoic, J. Geophys. Res., 100, 6093-6095.

Cande, S. C., J. L. LaBrecque, and W. F. Haxby (1988), Plate kinematics of the South Atlantic: Chron C34 to present, J. Geophys. Res., 93, 13,47913,492 .

Case, J. A., M. O. Woodburne, and D. S. Chaney (1988), A new genus of polypoloid marsupial from Antarctica, in Geology and Paleontology of Seymour Island, Antarctic Peninsula, Mem. Geol. Soc. Am., 169, 505521.

Cunningham, A. P. (1998), Geophysical investigations of the North Scotia Ridge, Ph.D. thesis, Univ. of London, London, UK.

Cunningham, A. P., P. F. Barker, and J. S. Tomlinson (1998), Tectonics and sedimentary environment of the North Scotia Ridge region revealed by side-scan sonar, J. Geol. Soc. London, 155, 941-956.

Cunningham, W. D., I. W. D. Dalziel, T. Y. Lee, and L. A. Lawver (1995), Southernmost South America-Antarctic Peninsula relative plate motions since $84 \mathrm{Ma}$ : Implications for the tectonic evolution of the Scotia Arc region, J. Geophys. Res., 100, 8257-8266.

Dalziel, I. W. D., R. H. Dott Jr., R. D. Winn Jr., and R. L. Bruhn (1975), Tectonic relations of South Georgia island to the southernmost Andes, Geol. Soc. Am. Bull., 86, 1034-1040.

De Wit, M. J. (1977), The evolution of the Scotia Arc as a key to the reconstruction of southwestern Gondwanaland, Tectonophysics, 37 $53-81$

Driscoll, M. L., and B. Parsons (1988), Cooling of the oceanic lithosphere-Evidence from geoid anomalies across the Udintsev and Eltanin fracture zones, Earth Planet. Sci. Lett., 88, 289-307.

Eagles, G. (2000), Modelling plate kinematics in the Scotia Sea, Ph.D. thesis, Univ. of Leeds, Leeds, UK.

Eagles, G. (2003), Plate tectonics of the Antarctic-Phoenix plate system since 15 Ma, Earth Planet. Sci. Lett., 217, 97-109.

Eagles, G., and R. A. Livermore (2002), Opening history of Powell Basin, Antarctic Peninsula, Mar. Geol., 185, 197-207.

Ewing, J. I., W. J. Ludwig, M. Ewing, and S. L. Eittreim (1971), Structure of the Scotia Sea and Falkland Plateau, J. Geophys. Res., 76, 7118-7137.

Gaina, C., R. D. Müller, J.-Y. Royer, J. Stock, J. Hardebeck, and P. Symonds (1998), The tectonic history of the Tasman Sea: A puzzle with 13 pieces, J. Geophys. Res., 103, 12,413-12,433.

Garrett, S. W., R. G. B. Renner, J. A. Jones, and K. J. McGibbon (1986), Continental magnetic anomalies and the evolution of the Scotia Arc, Earth Planet. Sci. Lett., 81, 273-281.

German, C. R., R. A. Livermore, E. T. Baker, N. I. Bruguier, D. P. Connelly, A. P. Cunningham, P. Morris, I. P. Rouse, P. J. Statham, and P. A. Tyler (2000), Hydrothermal plumes above the East Scotia Ridge: An isolated high-latitude back-arc spreading centre, Earth Planet. Sci. Lett., 184, 241-250.

Hamilton, I. W. (1989), Geophysical investigation of subduction related processes in the Scotia Sea, Ph.D. thesis, Univ. of Birmingham, Birmingham, UK.

Hellinger, S. J. (1981), The uncertainties of finite rotations in plate tectonics, J. Geophys. Res., 86, 9312-9318.

Heywood, K. J., A. C. Naveira Garaboto, and D. P. Stevens (2002), High mixing rates in the abyssal Southern Ocean, Nature, 415, 1011-1014.

Hill, I. A. (1978), A marine geophysical study of the crustal structure and evolution of the central Scotia Sea, South Atlantic, Ph.D. thesis, Univ. of Birmingham, Birmingham, UK

Hill, I. A., and P. F. Barker (1980), Evidence for Miocene back-arc spreading in the central Scotia Sea, Geophys. J. R. Astron. Soc., 63, 427-440.
Kennett, J. P., et al. (1975), Cenozoic paleoceanography in the southwest Pacific Ocean, Antarctic glaciation and the development of the CircumAntarctic Current, Initial. Rep. Deep Sea Drill. Project, 29, 1155-1169.

King, E. C., and P. F. Barker (1988), The margins of the South Orkney microcontinent, J. Geol. Soc. London, 145, 317-331.

King, E. C., G. Leitchenkov, J. Galindo-Zaldívar, A. Maldonado, and E. Lodolo (1997), Crustal structure and sedimentation in Powell Basin, Geology and Seismic Stratigraphy of the Antarctic Margin, 2, Antarct. Res. Ser., Vol. 71, edited by P. Barker and A. Cooper, pp. 75-93, AGU, Washington, D. C.

Kirkwood, B. H., J.-Y. Royer, T. C. Chang, and R. G. Gordon (1999), Statistical tools for estimating and combining plate rotations and their uncertainties, Geophys. J. Int., 137, 408-428.

Klepeis, K. A. (1994a), The Magallanes and Deseado fault zones: Major segments of the South American-Scotia transform plate boundary in southernmost South America, Tierra del Fuego, J. Geophys. Res., 99, $22,001-22,014$

Klepeis, K. A. (1994b), Relationship between uplift of the metamorphic core of the southernmost Andes and shortening in the Magallanes fold and thrust belt, Tierra del Fuego, Chile, Tectonics, 13, 882-904.

Klepeis, K. A., and J. A. Austin Jr. (1997), Contrasting styles of superposed deformation in the southernmost Andes, Tectonics, 16, 755-776.

Kraemer, P. E. (2003), Orogenic shortening and the origin of the Patagonian orocline (56 ${ }^{\circ} \mathrm{S}$ lat.), J. S. Am. Earth Sci., 15, 731-748.

LaBrecque, J. L., and P. D. Rabinowitz (1977), Magnetic anomalies bordering the continental margin of Argentina, AAPG Map 826.

Larter, R. D., and P. F. Barker (1991), Effects of ridge-crest-trench interaction on Antarctic-Phoenix spreading: Forces on a young subducting plate, J. Geophys. Res., 96, 19,583-19,607.

Lawver, L. A., and L. M. Gahagan (2003), Evolution of Cenozoic seaways in the circum-Antarctic region, Paleogeogr. Palaeoclimatol. Palaeoecol., $3115,1-27$

Lawver, L. A., T. Williams, and B. Sloan (1992), Seismic stratigraphy and heat flow of Powell Basin, Terra Antarct., 1, 309-310.

Livermore, R. A., D. McAdoo, and K. Marks (1994), Scotia Sea tectonics from high-resolution satellite gravity, Earth Planet. Sci. Lett., 123, 255268.

Livermore, R. A., et al. (2000), Autopsy on a dead spreading center: The Phoenix Ridge, Drake Passage, Antarctica, Geology, 28, 607-610.

Livermore, R. A., G. Eagles, P. Morris, and A. Maldonado (2004), Shackleton Fracture Zone: No barrier to early circumpolar ocean circulation, Geology, 32, 797-800.

Lodolo, E., F. Coren, A. A. Schreider, and G. Ceccone (1997), Geophysical evidence of a relict oceanic crust in the southwestern Scotia Sea, Mar. Geophys. Res., 19, 439-450.

Lorenzo, J. M., and J. C. Mutter (1988), Seismic stratigraphy and tectonic evolution of the Malvinas/Falkland Plateau, Rev. Bras. Geocienc., 18, $191-200$.

Ludwig, W. J. (1983), Geologic framework of the Falkland Plateau, Initial. Rep. Deep Sea Drill. Proj., 71, 281-292.

Ludwig, W. J., and P. D. Rabinowitz (1982), The collision complex of the North Scotia Ridge, J. Geophys. Res., 87, 3731-3740.

Ludwig, W. J., C. C. Windisch, R. E. Houtz, and J. I. Ewing (1978), Structure of Falkland Plateau and offshore Tierra del Fuego, Argentina, in Geological and Geophysical Investigations of Continental Margins, AAPG Mem., 29, 125-137.

Macfadyen, W. A. (1933), Fossil foraminifera from the Burdwood Bank and their geological significance, Discovery Rep., 7, $1-16$.

Maldonado, A., et al. (2000), Tectonics of an extinct ridge-transform intersection, Drake Passage (Antarctica), Mar. Geophys. Res., 21, 43-68.

Mao, S., and B. A. R. Mohr (1995), Middle Eocene dinocysts from Bruce Bank (Scotia Sea, Antarctica) and their paleoenvironmental and paleogeographic implications, Rev. Paleobot. Palynol., 86, 235-263.

Minster, J. B., T. H. Jordan, P. Molnar, and E. Haines (1974), Numerical modelling of instantaneous plate tectonics, Geophys. J. R. Astron. Soc., $36,541-576$.

Müller, R. D., and W. R. Roest (1992), FZs in the North Atlantic from combined Geosat and Seasat data, J. Geophys. Res., 97, 3337-3350.

Müller, R. D., D. T. Sandwell, B. E. Tucholke, J. G. Sclater, and P. R. Shaw (1991), Depth to basement and geoid expression of the Kane FZ: A comparison, Mar. Geophys. Res., 13, 105-129.

Nankivell, A. P. (1997), Tectonic evolution of the Southern Ocean between Antarctica, South America and Africa over the last 84 Ma, Ph.D. thesis, Univ. of Oxford, Oxford, UK.

Sandwell, D. T., and W. H. F. Smith (1997), Marine gravity anomaly from Geosat and ERS 1 satellite altimetry, J. Geophys. Res., 102, 10,03910,054 .

Shaw, P. R., and S. C. Cande (1990), High-resolution inversion for South Atlantic plate kinematics using joint altimeter and magnetic anomaly data, J. Geophys. Res., 95, 2625-2644. 
Smith, W. H. F., and D. T. Sandwell (1997), Global seafloor topography from satellite altimetry and ship depth soundings, Science, 277, 1956-1962.

Smith, W. H. F., and P. Wessel (1990), Gridding with continuous curvature splines in tension, Geophysics, 55, 293-305.

Storey, B. C., and D. I. M. Macdonald (1984), Processes of formation and filling of a Mesozoic back-arc basin on the island of South Georgia, in Marginal Basin Geology, edited by B. P. Kokelaar and M. F. Howells, Geol. Soc. Spec. Publ., 16, 207-218.

Thomas, T., R. A. Livermore, and F. Pollitz (2003), Motion of the Scotia Sea plates, Geophys. J. Int., 155, 789-804.

Tunnicliffe, V., A. G. McArthur, and D. McHugh (1998), A biogeographical perspective of the deep-sea hydrothermal vent fauna, Adv. Mar. Biol., $34,353-442$.

Tyrrell, G. W. (1945), Report on rocks from West Antarctica and the Scotia Arc, Discovery Rep., 23, 37-102.

Vanneste, L. E., and R. D. Larter (2002), Sediment subduction, subduction erosion and strain regime in the northern South Sandwich forearc, J. Geophys. Res., 107(B7), 2149, doi:10.1029/2001JB000396.

Wessel, P. (1989), XOVER: A cross-over error detector for track data, Comput. Geosci., 15, 333-346.
Wilson, D. S. (1993), Confidence intervals for motion and deformation of the Juan de Fuca plate, J. Geophys. Res., 98, 16,053-16,071.

Woodburne, M. O., and W. J. Zinsmeister (1982), Fossil land mammal from Antarctica, Science, 218, 284-286.

Zlotnicki, V., J. G. Sclater, I. O. Norton, and R. P. Von Herzen (1980), Heat flow through the floor of the Scotia, far south Atlantic and Weddell seas, Geophys. Res. Lett., 7, 421-424.

J. D. Fairhead, GeTECH, University of Leeds, Leeds LS2 9JT, UK. (jdf@getech.leeds.ac.uk)

G. Eagles, Alfred Wegener Institute for Polar and Marine Research, Columbusstraße, Bremerhaven D-27568, Germany. (geagles@ awi-bremerhaven.de)

R. A. Livermore and P. Morris, British Antarctic Survey, High Cross, Madingley Road, Cambridge CB3 0ET, UK. (ral@bas.ac.uk; pmor@ bas.ac.uk) 